\title{
Structure and Properties of Au-Sn Lead-Free Solders in Electronic Packaging
}

\author{
Xi Wang ${ }^{1}$, Liang Zhang ${ }^{1,2, *}$ and Mu-lan $\mathrm{Li}^{1}$ \\ ${ }^{1}$ School of Mechatronic Engineering, Jiangsu Normal University, Xuzhou 221116, China \\ ${ }^{2}$ State Key Laboratory of Advanced Welding and Joining, Harbin Institute of Technology, Harbin 150001, China
}

\begin{abstract}
The requirements for electronic devices in high-temperature environment such as avionics and automotive have promoted the development of high-temperature solders. The Au-20Sn solder, which is one of the hot topics of the current research in the field of electronic packaging, is widely used in flip-chip, light-emitting diode and hermetic package fields because of its good creep resistance, corrosion resistance and flux-free soldering. Recent research about the microstructure, wettability, interfacial intermetallic compounds, and mechanical properties of Au-20Sn solder were reviewed. This paper focuses on the interfacial reaction of $\mathrm{Au}-20 \mathrm{Sn}$ with different substrates and the mechanical properties of $\mathrm{Au}-20 \mathrm{Sn}$ solder joints. In addition, the current research shortages of Au-20Sn solders and the development directions are presented. [doi:10.2320/matertrans.MT-M2021200]
\end{abstract}

(Received October 11, 2021; Accepted November 10, 2021; Published January 25, 2022)

Keywords: solder, Au-Sn, IMC, microstructures, mechanical properties

\section{Introduction}

Conventional $\mathrm{Sn}-\mathrm{Pb}$ solders have the advantages of good mechanical strength, creep resistance, and thermal stability. However, $\mathrm{SnPb}$ solders have been banned in many countries because lead is harmful to the ecology and human. ${ }^{1-3)}$ With the development of lead-free electronics, researchers have conducted a lot of research on lead-free solders, trying to find solders that can replace traditional $\mathrm{Sn}-\mathrm{Pb}$ solders. Currently, Sn-based solders have the most potential to replace $\mathrm{SnPb}$ solders. ${ }^{4}$ ) Solders that are suitable for lowtemperature applications are $\mathrm{SnBi}^{5)} \mathrm{SnAg},{ }^{6)} \mathrm{SnAgCu},{ }^{7,8)}$ and $\mathrm{SnZn}^{9}{ }^{9} \mathrm{SnSb}^{10)}$ and $\mathrm{AuSn}^{11)}$ are suitable for hightemperature applications. With the development of the electronics industry, solders are used in high-temperature environments increasingly but there are relatively little researches about high-temperature solders in numerous references. ${ }^{12)}$ Therefore, it was necessary to find hightemperature solders that could be adapted to the automotive and avionics sectors. etc.

$\mathrm{Au}-20 \mathrm{Sn}$ is a eutectic solder with a eutectic temperature of $278^{\circ} \mathrm{C}$. The $\mathrm{Au}-20 \mathrm{Sn}$ solder matrix consists of $\zeta-\mathrm{Au}_{5} \mathrm{Sn}$ and $\delta$-AuSn phase. ${ }^{13)}$ The $\zeta$-Au ${ }_{5} \mathrm{Sn}$ phase has superior mechanical properties and reliability, so $\mathrm{Au}-20 \mathrm{Sn}$ solder is stable at high temperatures. ${ }^{14)} \mathrm{Au}-20 \mathrm{Sn}$ solder, which has the advantages of good creep resistance, corrosion resistance, and flux-free welding, is one of the candidate solders to replace $\mathrm{Pb}$-based solders that have a high melting point. ${ }^{15)}$ However, Au-Sn solders have some drawbacks and research deficiencies. The brittleness of $\zeta-\mathrm{Au}_{5} \mathrm{Sn}$ intermetallic compounds (IMC) is relatively high, and Au-20Sn solders cannot be easily prepared by conventional casting and rolling processes, so researchers have carried many research on the preparation of $\mathrm{Au}-20 \mathrm{Sn}$ solders. ${ }^{16)}$ Most of the electronic components fail because of the breakdown of the solder joints, so the evaluation of the reliability of AuSn solder joints is one of the hot topics of research in electronic packaging. In addition, $\mathrm{Au}-20 \mathrm{Sn}$ solder has relatively high cost because it contains 80 mass $\%$ Au elements.

*Corresponding author, E-mail: zhangliang@jsnu.edu.cn
According to the research results of $\mathrm{Au}-\mathrm{Sn}$ solders at home and abroad in recent years, the microstructure of $\mathrm{Au}-\mathrm{Sn}$ solders prepared by different preparation processes and the wetting behavior under different conditions are summarized. What's more, the interfacial reaction of $\mathrm{Au}-\mathrm{Sn}$ solders with different substrates and the mechanical properties of the solder joints are highlighted in this review. Finally, the research deficiencies and development trends of $\mathrm{Au}-\mathrm{Sn}$ solders are summarized in the hope of bringing valuable references for the research of $\mathrm{Au}-\mathrm{Sn}$ solders in the future.

\section{Microstructure}

Based on the phase diagram of Au-Sn binary alloy, it is known that $\mathrm{Au}-20 \mathrm{Sn}$ is the binary eutectic region with a melting point of $278^{\circ} \mathrm{C}$. The eutectic reaction is shown in eq. (1). Au-20Sn solder is very brittle at room temperature, mainly because the solder contains the brittle $\zeta^{\prime}-\mathrm{Au}_{5} \mathrm{Sn}$ phase, so it is not easy to prepare by conventional processing. ${ }^{17)}$

$$
\mathrm{L} \rightarrow \xi-\mathrm{Au}_{5} \mathrm{Sn}+\delta-\mathrm{AuSn}
$$

The $\mathrm{Au}$ and $\mathrm{Sn}$ laminated process is a preparation method for preparing Au-Sn solder. The laminated composite method is to stack $\mathrm{Au}$ and $\mathrm{Sn}$ layers in the arrangement of $\mathrm{Au} / \mathrm{Sn} /$ $\mathrm{Au} / \ldots . . / \mathrm{Sn} / \mathrm{Au}$ and then cold roll them into shape. The stacked diffusion method is a homogenization annealing based on the stacked composite method. ${ }^{18)}$ It was found that $\mathrm{AuSn}, \mathrm{AuSn}_{2}$, and $\mathrm{AuSn}_{4}$ IMC were formed after annealed at the $\mathrm{Au} / \mathrm{Sn}$ interface. The proportion of their thicknesses throughout the annealing process was approximately 1:1:4. The link between the total thickness of the interface and the annealing time is shown in eq. (2).

$$
l=k\left(t / t_{0}\right)^{n}
$$

where $l$ is the total thickness, $t_{0}$ is the annealing time, and $k$ and $n$ are $2.7 \times 10^{-7}$ and 0.42 , respectively. Wei et al. ${ }^{19)}$ used a stacked diffusion method to make $\mathrm{Au} / \mathrm{Sn}$ combinations to form a fast diffusion system, and also found that AuSn, $\mathrm{AuSn}_{2}$, and $\mathrm{AuSn}_{4}$ IMC were formed during rolling. With the rapid diffusion of $\mathrm{Au}$ and $\mathrm{Sn}$, the $\mathrm{Au}-\mathrm{Sn}$ solder formed by pressing was annealed at a temperature of $453 \mathrm{~K}$. It was 


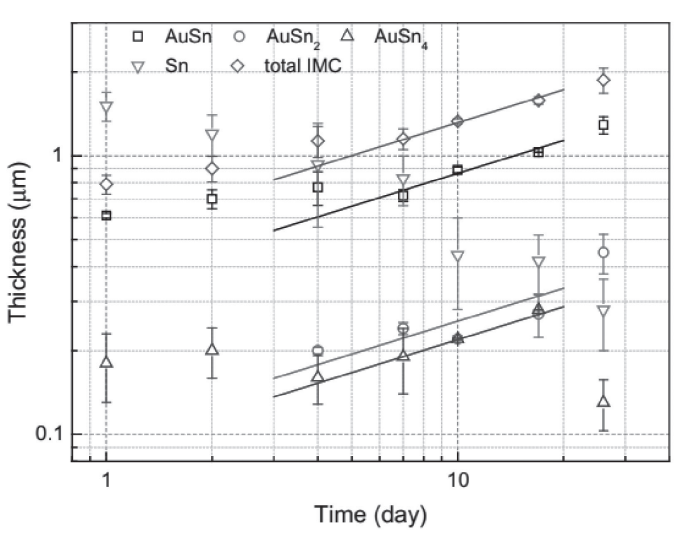

(a)

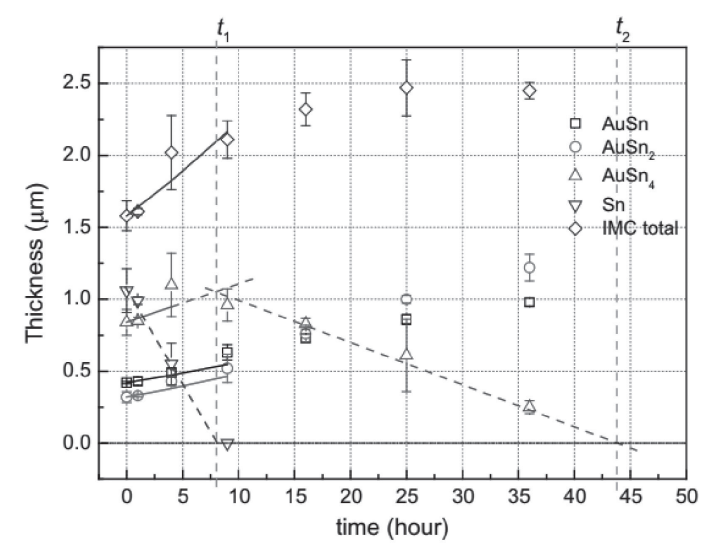

(b)

Fig. 1 The relationship between thickness of each IMC layer and the storage time at (a) $298 \mathrm{~K}$ and (b) $333 \mathrm{~K}$.

found that $\mathrm{AuSn}, \mathrm{AuSn}_{2}$ and $\mathrm{AuSn}_{4}$ IMC transform into $\zeta$ and $\delta(\mathrm{AuSn})$ phases. In contrast, the $\mathrm{Sn}$ and $\mathrm{AuSn}_{4}$ phases were melted to increase the brittleness of the solder when the solder was annealed at $543 \mathrm{~K}$, so the $\mathrm{Au}-\mathrm{Sn}$ solders prepared by the pressure ligation process should be applied at $543 \mathrm{~K}$. The $\mathrm{Au}-\mathrm{Sn}$ solders prepared by the lamination process are not sufficiently alloyed resulting in non-uniform microstructure and unstable melting point, thus making the solder poorly welded. Therefore, the laminated process is gradually replaced by other processes.

The electroplating deposition process refers to the deposition of $\mathrm{Au}$ and $\mathrm{Sn}$ ions on a substrate after a redox reaction to form $\mathrm{Au}-\mathrm{Sn}$ films. Xu et al. ${ }^{20)}$ found that $\mathrm{AuSn}$, $\mathrm{AuSn}_{2}$ and $\mathrm{AuSn}_{4}$ IMC were formed at $\mathrm{Au} / \mathrm{Sn}$ layers plated on metallized $\mathrm{Si}$ wafers at $298 \mathrm{~K}$ and $333 \mathrm{~K}$. Their thicknesses varied with the aging time as shown in Fig. 1. The interfacial reaction of Au-Sn films affects the ensuing solid-liquid phase diffusion linkage (SLID) during storage. Therefore, Au/Sn plating prepared by electroplating deposition should be stored at low-temperature. Yoon et al. ${ }^{21)}$ prepared $\mathrm{Au}-20 \mathrm{Sn}$ bumps with an average diameter of about $80 \mu \mathrm{m}$ on a flip-chip using electroplating. Only $(\mathrm{Ni}, \mathrm{Au})_{3} \mathrm{Sn}_{2}$ IMC was formed between $\mathrm{Au}-20 \mathrm{Sn}$ solder and $\mathrm{Ni}$ under bump metallurgy (UBM) after aging at $150^{\circ} \mathrm{C}$. All of $(\mathrm{Ni}, \mathrm{Au})_{3} \mathrm{Sn}_{2} \mathrm{IMC}$ were transformed into $(\mathrm{Au}, \mathrm{Ni}) \mathrm{Sn}$ phase, and the $(\mathrm{Au}, \mathrm{Ni}) \mathrm{Sn}$ IMC reacted with $\mathrm{Ni} \mathrm{UBM}$ to form $(\mathrm{Ni}, \mathrm{Au})_{3} \mathrm{Sn}_{2}$ phase after aging for $1000 \mathrm{~h}$ at $250^{\circ} \mathrm{C}$. The electroplating deposition process is less expensive and can prepare solder layers of various shapes. The electroplating deposition process requires an electroplating solution. Although cyanide-containing electroplating solution is stable and suitable for industrial requirements, cyanide is hazardous to humans and ecological environment, so a suitable cyanidefree electroplating solution needs to be found to meet the production requirements. In addition, $\mathrm{Au}-\mathrm{Sn}$ films prepared by the electroplating process should be stored at low temperatures to hinder the growth of IMC at the $\mathrm{Au} / \mathrm{Sn}$ interface.

The rapid solidification process involves the formation of thin strips of liquid metal in a single pass under centrifugal force. The microstructure of $\mathrm{Au}-20 \mathrm{Sn}$ solder prepared by the single-roll rapid solidification technology is the same as that prepared by the cast-roll process, and both consist of eutectic organization $\left(\zeta^{\prime}-\mathrm{Au}_{5} \mathrm{Sn}+\delta\right.$-AuSn $)$ and $\zeta^{\prime}-\mathrm{Au}_{5} \mathrm{Sn}$ phase, as shown in Fig. 2.2) It was found that the grain of $\mathrm{Au}-20 \mathrm{Sn}$ solder prepared by single-roll rapid solidification technology is finer and more uniform, so its melting point reduce, and specific surface area and surface energy increase. Huang et al. ${ }^{17)}$ found that the $\zeta^{\prime}-\mathrm{Au}_{5} \mathrm{Sn}$ phase was still present in the solder at very fast cooling rates, and the application of a magnetic field effectively suppressed the growth of $\zeta^{\prime}-\mathrm{Au}_{5} \mathrm{Sn}$ phase during the rapid solidification of $\mathrm{Au}-20 \mathrm{Sn}$ solder. The fracture stress and the fracture strain of the solder were 1456.7 $\mathrm{MPa}$ and $64 \%$ under the action of the magnetic field, respectively. However, $\zeta^{\prime}-\mathrm{Au}_{5} \mathrm{Sn}$ still existed at the conventional cooling rate. The crystallization process of $\mathrm{Au}-20 \mathrm{Sn}$ rapid solidification and conventional solidification under magnetic field induction is shown in Fig. 3. The rapid solidification process which is a simple procedure with low cost has a broad application prospect in the preparation of $\mathrm{Au}-20 \mathrm{Sn}$ solder.

What's more, Tabatabaei et al. ${ }^{23)}$ successfully prepared 2-10 nm Au-Sn alloy nanoparticles (ANPs) by chemical reduction method. The ANPs can reflow at lower temperatures, thus reducing the thermal stress in electrical devices and being more suitable for electronic devices operating at high temperatures. The $\mathrm{Au}-20 \mathrm{Sn}$ solder prepared by planar flow casting (PFC) method consists of inhomogeneous AuSn $\mathrm{IMC}$ and $\mathrm{Au}_{5} \mathrm{Sn} \mathrm{IMC}$, and the grains of $\mathrm{Au}-20 \mathrm{Sn}$ solder prepared by $\mathrm{PFC}$ transformed into coarse and homogeneous phases with heat-treated at $170^{\circ} \mathrm{C} .{ }^{24)}$ The plasticity of the heat-treated solder was increased, and the yield and tensile strengths of solder were reduced. He et al. ${ }^{25)}$ made the initial thickness of $4 \mathrm{~mm}$ of cast Au-20Sn solder into a thickness of $48 \mu \mathrm{m}$ of $\mathrm{Au}-20 \mathrm{Sn}$ film by hot rolling. During the hot rolling process, the eutectic lamellar microstructure of the $\mathrm{Au}-20 \mathrm{Sn}$ solder underwent plastic deformation. This process promoted the spheroidization of the microstructure. The spheroidization of the AuSn IMC was more pronounced than that of the $\mathrm{Au}_{5} \mathrm{Sn}$ IMC because the AuSn layer had a higher strain accumulation as well as a more random strain distribution. ${ }^{26)}$

\section{Wettability}

Wettability of solders defined as the ability of the liquid solder to spread on the surface of the substrate. ${ }^{27)}$ Good 

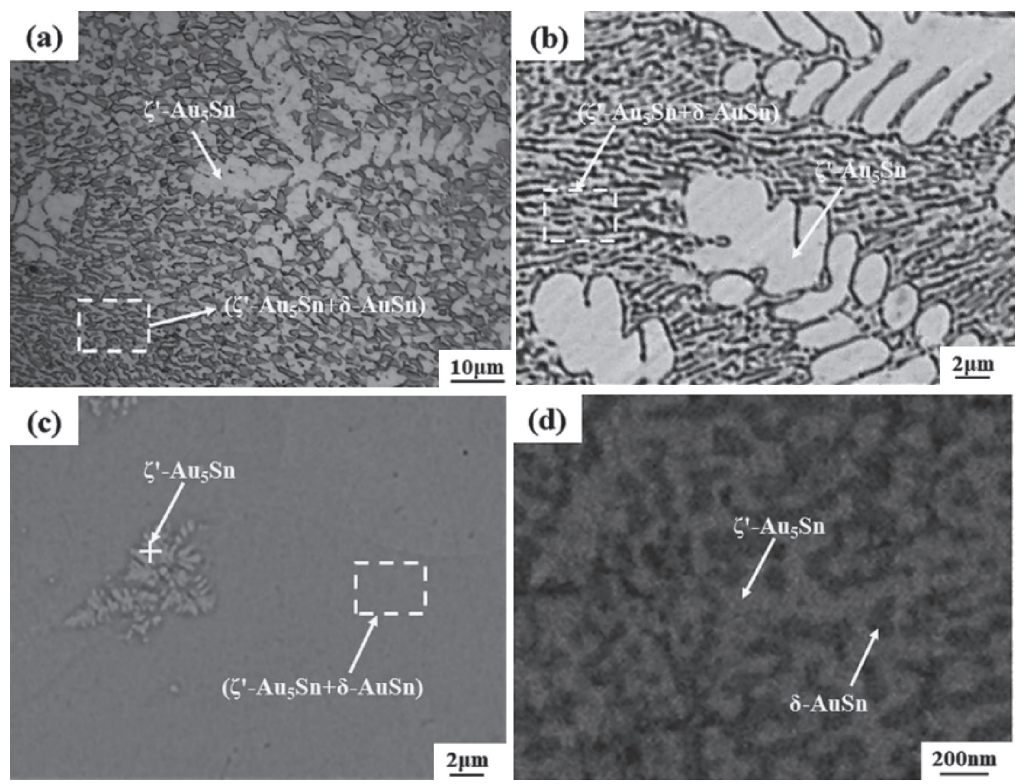

Fig. 2 The microstructure of Au-20Sn solder: (a) as-cast solder, (b) enlarged view of the marked portion of (a), (c) rapidly solidified solder, (d) enlarged view of the marked portion of (c).

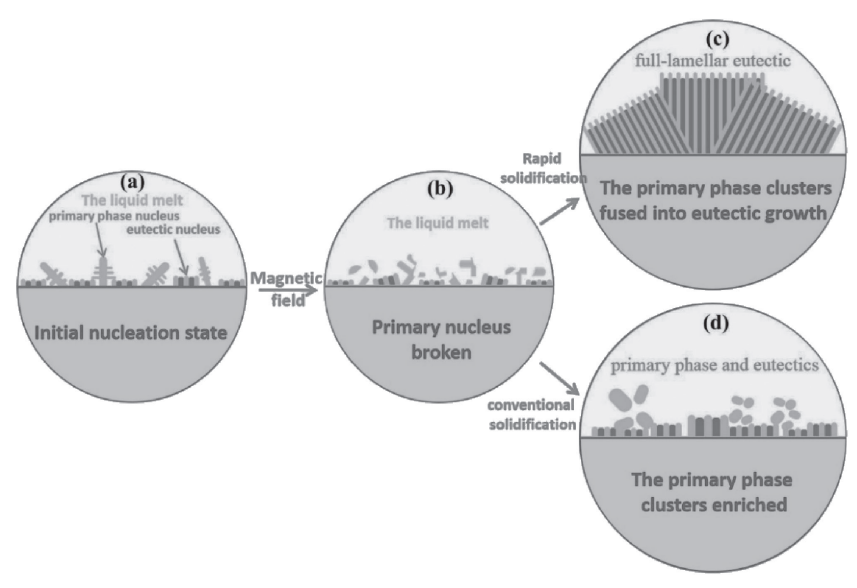

Fig. 3 The schematic of $\mathrm{Au}-\mathrm{Sn} 20$ crystallization process under magneticfield-induced rapid solidification and conventional solidification.

wettability which is the key to soldering welding $\mathrm{Ag}$ and $\mathrm{Sn}-$ $\mathrm{Au}-\mathrm{Ni}$ solders on Ni substrates was larger than $\mathrm{Cu}$ substrates, as shown in Fig. 4, indicating better wetting of both solders on Ni substrates. ${ }^{28)}$ The rapid reaction of $\mathrm{Sn}$ atoms with $\mathrm{Cu}$ forms $\mathrm{Cu}_{6} \mathrm{Sn}_{5}$ IMC in the solder because the diffusion speed of $\mathrm{Cu}$ atoms is greater than $\mathrm{Ni}$ atoms. It reduces the wettability of the solder on the $\mathrm{Cu}$ substrate. The $\mathrm{Au}-20 \mathrm{Sn}$ solder prepared by the rapid solidification method has a larger spread area of $14.48 \mathrm{~mm}^{2}$ compared to as-cast $\mathrm{Au}-20 \mathrm{Sn}$ solder, as shown in Fig. 5. It is $1.43 \mathrm{~mm}^{2}$ larger than as-cast $\mathrm{Au}-20 \mathrm{Sn}$ solder. ${ }^{22)}$ Vianco et al. ${ }^{29)}$ investigated the reasons why $\mathrm{Au}-20 \mathrm{Sn}$ was not incomplete wetting on the Au surface of $\mathrm{Fe}-\mathrm{Ni}$ alloy on sealed ceramics and found that $\mathrm{Fe}$ and $\mathrm{Ni}$ prevented the wetting and diffusion of the solder. The presence of element $\mathrm{C}$ in the $\mathrm{Au}$ layer also affected the wettability of the solder. When the $\mathrm{C}$ contaminants in the $\mathrm{Au}$ layer are removed, there is little danger to the reliability of the solder joint.

The oxide film is mainly consist of $\mathrm{SnO}_{2}$ and $\mathrm{SnO}$ on the surface of $\mathrm{Au}-20 \mathrm{Sn}$ solder, and the formation process is

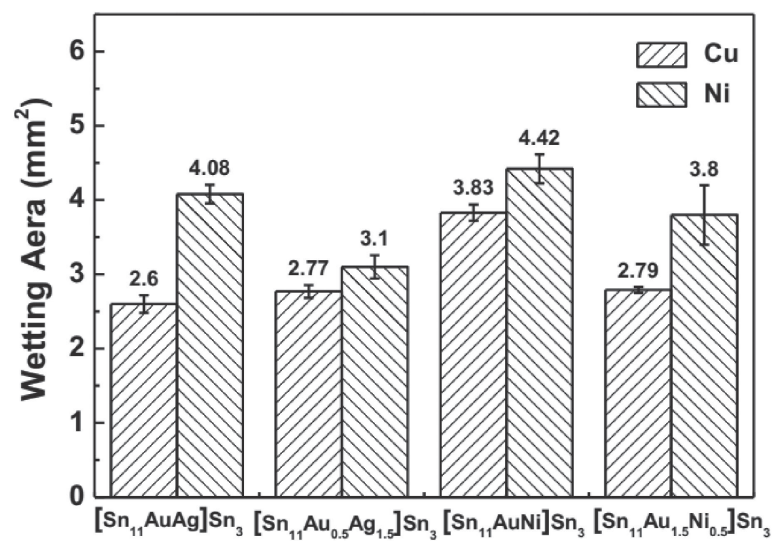

Fig. 4 The histogram on the wetting area of $\mathrm{Sn}-\mathrm{Au}-\mathrm{Ag}(\mathrm{Ni})$ solders on $\mathrm{Cu}$ and Ni substrates.
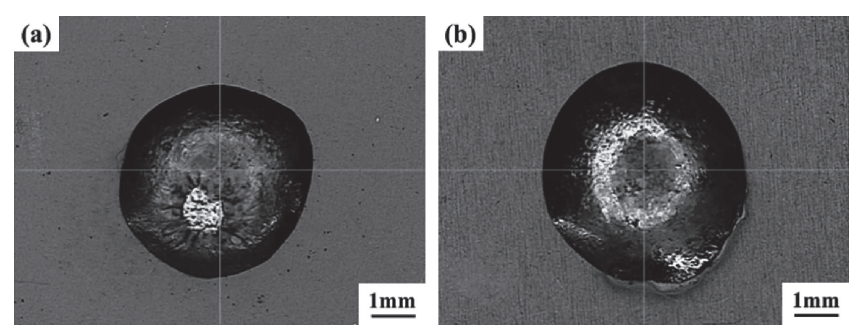

Fig. 5 The images of two Au-20Sn eutectic solder ribbons after the spreading experiment: (a) cast-rolling, (b) rapid solidification-rolling.

shown in Fig. 6. ${ }^{30)}$ As the oxygen content increases, the spreading area of the solder decreases. The spreading area of the solder is $96.5 \mathrm{~mm}^{2}$ with the oxygen content of $16 \mathrm{ppm}$. As the oxygen content increases to $102 \mathrm{ppm}$, the spreading area decreases by $45.8 \%$. The spreading area of $\mathrm{Au}-20 \mathrm{Sn}$ solder on $\mathrm{Cu}$ substrate decreases as the oxygen content increases. ${ }^{31)}$ As the oxygen content increased from 18 to $77 \mathrm{ppm}$, the spread area decreased from 92.8 to $49.2 \mathrm{~mm}^{2}$, mainly because the oxide film on the surface of the molten 


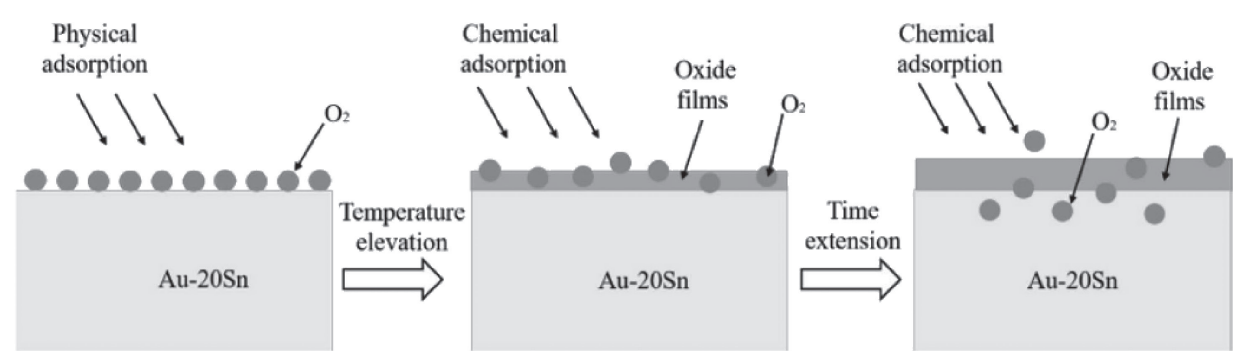

Fig. 6 The formation process of oxide films on surface of Au-20 solder.
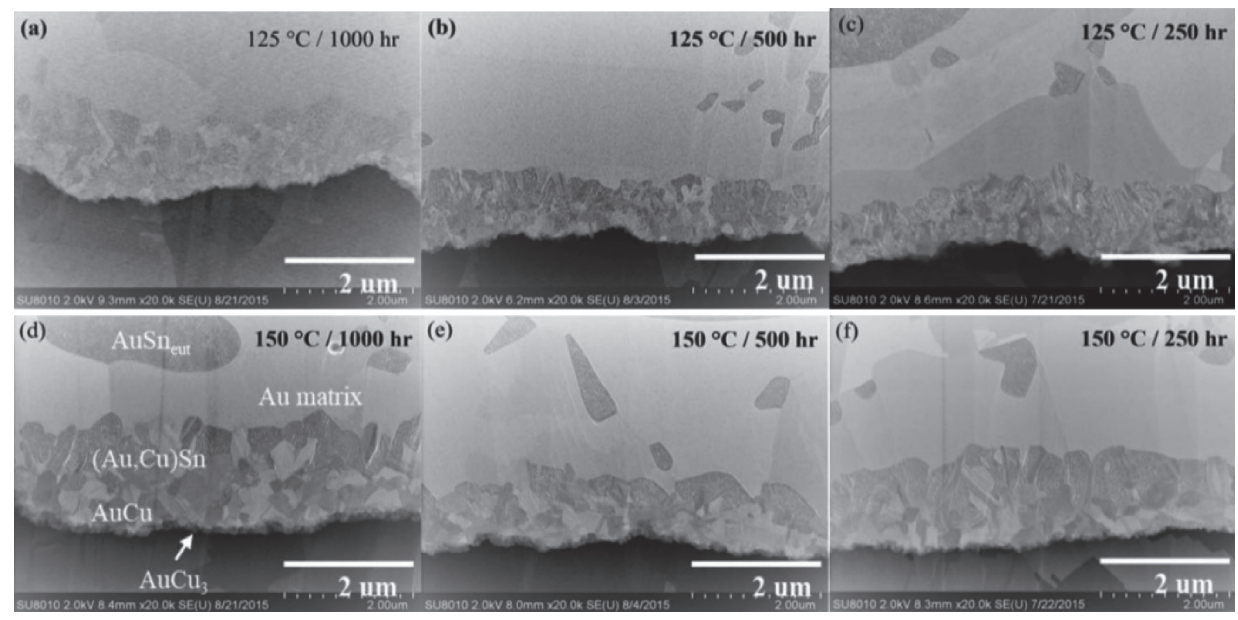

Fig. 7 The SEM images of microstructure of $\mathrm{Au}-20 \mathrm{Sn} / \mathrm{Cu}$ solder joints with high temperature storage test for $250 \mathrm{~h}$ to $1000 \mathrm{~h}$. (a)-(c) and (d)-(f) are isothermal storage at $125^{\circ} \mathrm{C}$ and $150^{\circ} \mathrm{C}$, respectively.

$\mathrm{Au}-\mathrm{Sn}$ solder increased the surface tension. Secondly, the oxides consist of high melting point $\mathrm{SnO}$ and $\mathrm{SnO}_{2}$ in the $\mathrm{Au}-20 \mathrm{Sn}$. It reduces the fluidity of the solder, resulting in a reduction in the spread area of the $\mathrm{Au}-20 \mathrm{Sn}$ on the $\mathrm{Cu}$ substrate.

\section{Interfacial Reactions}

The interfacial IMC acts as a bond between the solder and the substrate at the interface, and it improves the mechanical properties of the solder joint, but too much IMC can cause the interface to fracture due to its brittleness. ${ }^{32)}$

$\mathrm{Cu}$ substrate is a commonly used in the field of electronic packaging. At the beginning of reflow, irregular $\zeta-(\mathrm{Au}, \mathrm{Cu})_{5}$ IMC and layered $\mathrm{AuCu} \mathrm{IMC}$ were formed at $\mathrm{Au}-20 \mathrm{Sn} / \mathrm{Cu}$ solder joints. ${ }^{33)}$ The growth of dendritic $\zeta-(\mathrm{Au}, \mathrm{Cu})_{5}$ IMC was discovered in the substrate because of the diffusion of $\mathrm{Cu}$ elements when the reflow time reached $60 \mathrm{~min}$. The $\mathrm{Au}_{2} \mathrm{Cu}_{6} \mathrm{Sn}_{2}$ IMC was formed in $\mathrm{Au}-20 \mathrm{Sn} / \mathrm{Cu}$ solder joints prepared using the electrodeposition process, with the reaction equations shown in eq. (3) and (4). ${ }^{34)}$ Yoon et al. ${ }^{35)}$ found the evolution of the interfacial microstructure of fluxfree soldered $\mathrm{Au}-20 \mathrm{Sn} / \mathrm{Cu}$ joints during reflow and aging treatment. Only an irregular layer of $\zeta(\mathrm{Cu})$ phase was formed at the interface at the beginning of reflow, and an $\mathrm{AuCu}$ IMC was generated in the interface as the reflow time increased. After aging at $250^{\circ} \mathrm{C}$, the $\zeta(\mathrm{Cu}), \mathrm{AuCu}$, and $\mathrm{AuCu}_{3} \mathrm{IMC}$ layers were present at the interface of $\mathrm{Au}-20 \mathrm{Sn}$ solder and $\mathrm{Cu}$ substrate. The $(\mathrm{Au}, \mathrm{Cu}) \mathrm{Sn}$ and $\mathrm{AuCu}$ IMC layers in $\mathrm{Au}-$ $20 \mathrm{Sn} / \mathrm{Cu}$ solder joints thickened with the increase of aging time. ${ }^{32)}$ The thickness of IMC layer was increased because of the diffusion of $\mathrm{Au}$ and $\mathrm{Sn}$ elements. However, the diffusion of $\mathrm{Au}$ and $\mathrm{Sn}$ elements is gradually suppressed as the $(\mathrm{Au}, \mathrm{Cu}) \mathrm{Sn}$ IMC thickens, so that the $\mathrm{AuCu}_{3} \mathrm{IMC}$ appears underneath the $\mathrm{AuCu} \mathrm{IMC}$, as shown in Fig. 7. The $(\mathrm{Au}, \mathrm{Cu})_{5} \mathrm{Sn}$ phase was generated in $\mathrm{Au}-29 \mathrm{Sn} / \mathrm{Cu}$ solder joint formed by transient liquid phase bonding (TLP). As the welding time increases to $60 \mathrm{~min}, \mathrm{Cu} / \mathrm{Au}-\mathrm{Sn} / \mathrm{Cu}$ solder joints consist mainly of $\alpha^{\prime}(\mathrm{Au}), \alpha(\mathrm{Au})$, and $\mathrm{Au}_{6.6} \mathrm{Cu}_{9.6} \mathrm{Sn}_{3.8}$ $\mathrm{IMC}$, as shown in Fig. 8. ${ }^{36)} \mathrm{Du}$ et al. ${ }^{37)}$ found that three IMC layers with a total thickness of about $2 \mu \mathrm{m}$ exist in $\mathrm{Au}-$ 20Sn/Cu solder joints bonded by TLP. The IMC layer which is face-centered cubic with transient atomic ratios is $\mathrm{Au}-\mathrm{Cu}$ solid solution adjacent to $\mathrm{Cu}$ layer. The other two layers have a more complex microstructure with many nanoscale IMCs. Liu et al. ${ }^{38)}$ found the $\mathrm{AuSn} / \mathrm{AuSn}_{2} / \mathrm{AuSn}_{4} / \mathrm{Sn} /$ $(\mathrm{Cu}, \mathrm{Au})_{6} \mathrm{Sn}_{5} / \mathrm{Cu}_{3} \mathrm{Sn}$ layer at the interface of the $\mathrm{Au}-20 \mathrm{Sn}$ solder and $(\mathrm{Sn}) \mathrm{Cu}$ substrate during reflow at $250^{\circ} \mathrm{C}$, and the $\mathrm{AuSn}_{4}$ IMC layer gradually disappeared as the reflow time increased. The $\mathrm{AuSn}_{2}$ and $(\mathrm{Cu}, \mathrm{Au})_{6} \mathrm{Sn}_{5} \mathrm{IMC}$ at the solder joint gradually disappeared and the interfacial structure was transformed into $\mathrm{AuSn} / \mathrm{Cu}_{3} \mathrm{Sn}$ after isothermal aging treatment.

$$
\begin{gathered}
2 \mathrm{Au}-\mathrm{Sn}+6 \mathrm{Cu} \rightarrow \mathrm{Au}_{2} \mathrm{Cu}_{6} \mathrm{Sn}_{2} \\
2 \mathrm{Au}_{5} \mathrm{Sn}+6 \mathrm{Cu} \rightarrow \mathrm{Au}_{2} \mathrm{Cu}_{6} \mathrm{Sn}_{2}+8 \mathrm{Au}
\end{gathered}
$$

In order to block the diffusion of $\mathrm{Cu}$ and prolong the service life of electronic devices, $\mathrm{Ni}$ is often plated on the $\mathrm{Cu}$ substrate as a barrier layer. $\mathrm{Ni} / \mathrm{Au}-\mathrm{Sn} / \mathrm{Ni}$ solder joint form $\mathrm{Ni}_{3} \mathrm{Sn}_{2}$ IMC in the course of welding. The $\mathrm{Ni}_{3} \mathrm{Sn}_{2}$ IMC 

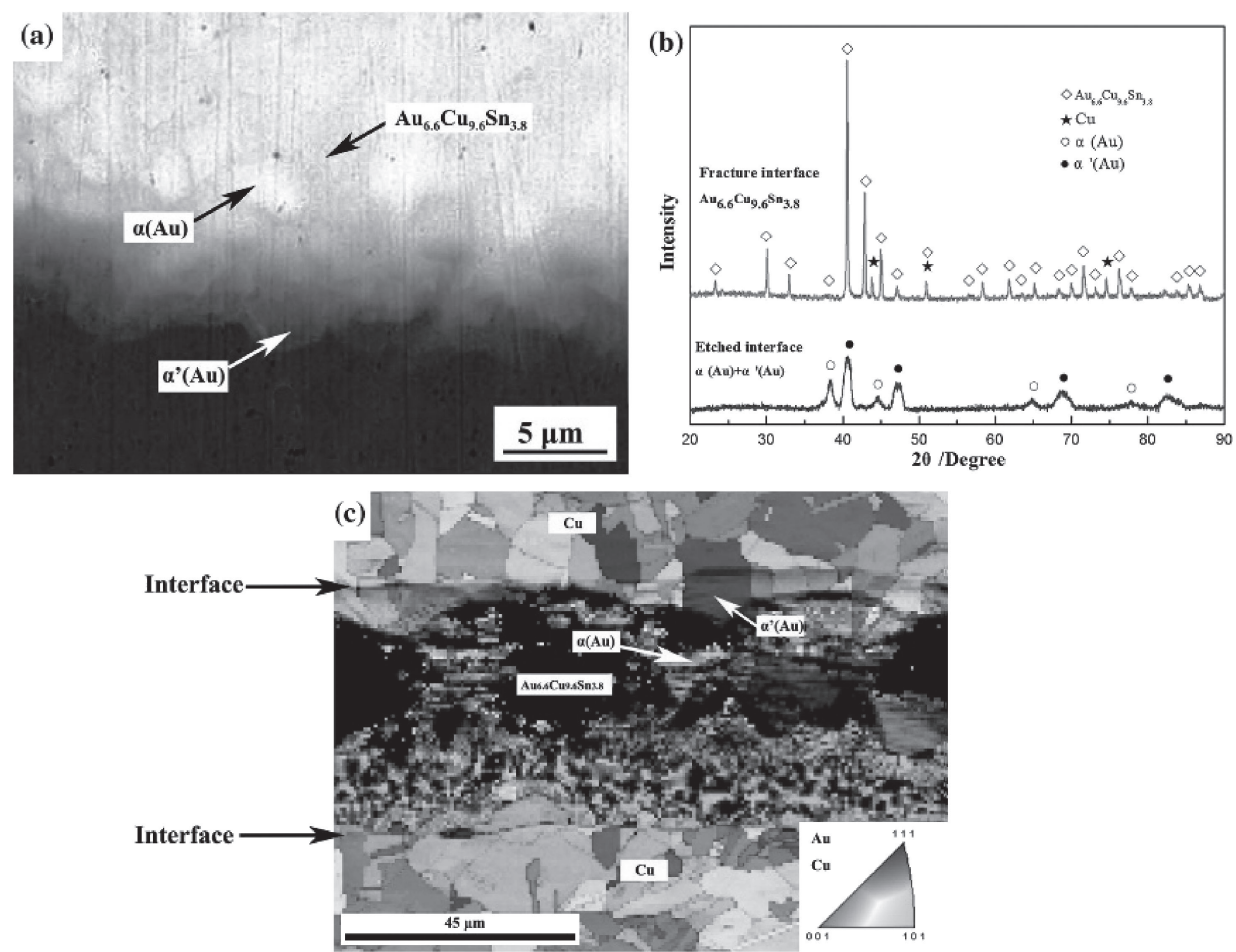

Fig. $8 \mathrm{Cu} / \mathrm{Au}-29 \mathrm{Sn} / \mathrm{Cu}$ solder joint after welded at $300^{\circ} \mathrm{C}$ for $60 \mathrm{~min}$ (with pressure): (a) cross-sectional micrograph; (b) XRD (diffraction of X-rays) patterns; (c) EBSD (Electron Backscattered Diffraction) OIM (imaging microscopy)+IQ (image quality) micrograph.
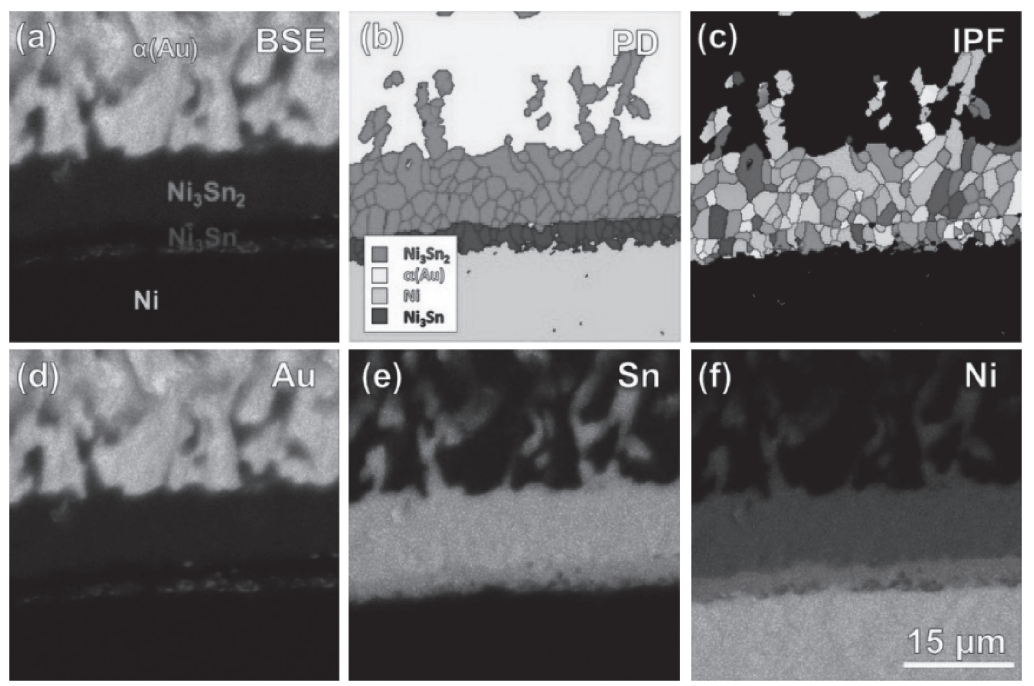

Fig. 9 The EBSD of the Ni/Au-Sn/Ni solder joint after exposed at $450^{\circ} \mathrm{C}$ for $400 \mathrm{~h}$. (a) The backscattered electron (BSE) image. (b) The phase distribution (PD) image. (c) The inverse pole figure (IPF). Corresponding EDX maps of (d) Au, (e) Sn, and (f) Ni.

transforms into $\mathrm{Au}_{5} \mathrm{Sn}+\alpha(\mathrm{Au}) \mathrm{IMC}$ after 60 min of treatment at $350^{\circ} \mathrm{C}^{39)}$ After $400 \mathrm{~h}$ of treatment at $450^{\circ} \mathrm{C}$, it was observed that a $\mathrm{Ni}_{3} \mathrm{Sn}$ IMC layer was formed at the interface of the $\mathrm{Ni}$ substrate and the $\mathrm{Ni}_{3} \mathrm{Sn}_{2}$ IMC layer, and $\mathrm{Au}_{5} \mathrm{Sn}$ IMC was completely reacted, as shown in Fig. 9. No voids were found in the $\mathrm{Ni} / \mathrm{Au}-\mathrm{Sn} / \mathrm{Ni}$ solder joints after the thermal cycling treatment because the Ni substrate was able to hinder the diffusion of $\mathrm{Au}$ elements. The $(\mathrm{Au}, \mathrm{Ni})_{5} \mathrm{Sn} \mathrm{IMC}$ and (Au,Ni)Sn IMC were formed at $\mathrm{Au}-20 \mathrm{Sn}$ and $\mathrm{Ni}$ substrate after $2 \mathrm{~min}$ of reflow at $290^{\circ} \mathrm{C}$, and $(\mathrm{Au}, \mathrm{Cu})_{5} \mathrm{Sn}$ IMC and (Au,Ni)Sn IMC were formed in $\mathrm{Au}-20 \mathrm{Sn}$ and $\mathrm{Cu}$ substrate. In addition, $\mathrm{Au}-20 \mathrm{Sn} / \mathrm{Ni}$ solder joint has more thermally stable than $\mathrm{Au}-20 \mathrm{Sn} / \mathrm{Cu}$ solder joints at $240^{\circ} \mathrm{C}$, therefore, Ni layer was more suitable than $\mathrm{Cu}$ as a diffusion barrier layer. ${ }^{40)}$ The matrix of $\mathrm{Au}-20 \mathrm{Sn}$ solder consists of $\mathrm{Au}_{5} \mathrm{Sn}$ and $\mathrm{AuSn}$ phases. A layered (Au,Ni)Sn IMC and a scalloped (Au,Ni) ${ }_{5} \mathrm{Sn}$ IMC layer were formed at $\mathrm{Au}-20 \mathrm{Sn} / \mathrm{Ni}$ solder joint. ${ }^{41)}$ Initially, the microstructure of $\mathrm{Au}-20 \mathrm{Sn} / \mathrm{Ni}$ solder joint consists of (Au,Ni)Sn and $(\mathrm{Au}, \mathrm{Ni})_{5} \mathrm{Sn} / \mathrm{Ni}$ layer, and the microstructure eventually changed to $(\mathrm{Au}, \mathrm{Ni})_{5} \mathrm{Sn}$ and $(\mathrm{Au}, \mathrm{Ni}) \mathrm{Sn} / \mathrm{Ni}$ layer with the increase of reflow time because of the diffusion of $\mathrm{Sn}$ elements through $\mathrm{Au}_{5} \mathrm{Sn}^{42)}$ The crosssections of microstructure and elemental concentrations of $\mathrm{Au}-20 \mathrm{Sn} / \mathrm{Ni}$ solder joints reflowed at $350^{\circ} \mathrm{C}$ for $15 \mathrm{~min}$ and 

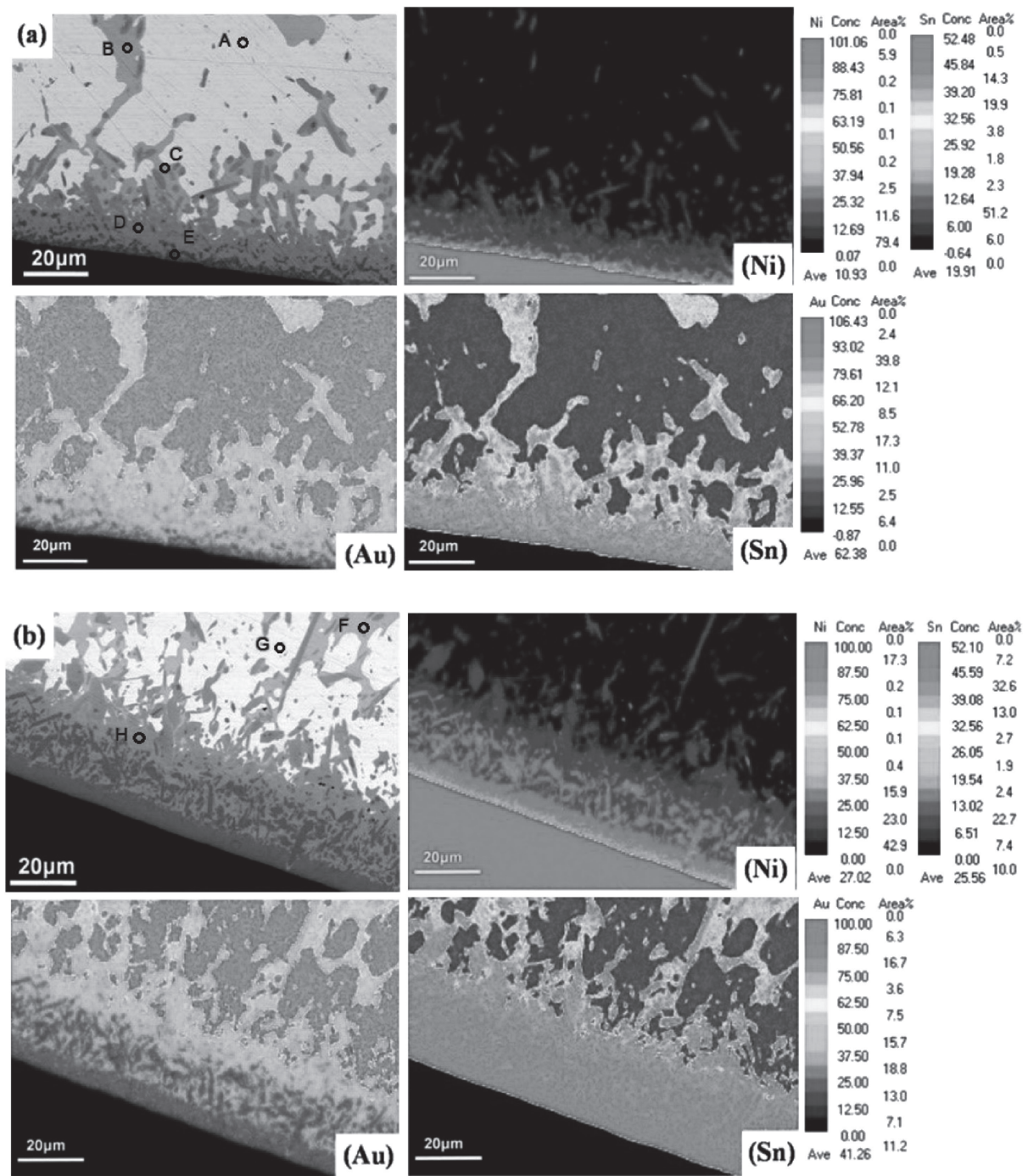

Fig. 10 Electron Probe Micro Analysis (EPMA) element mapping of the $\mathrm{Au}-20 \mathrm{Sn} / \mathrm{Ni}$ solder joint after reflowing at $350^{\circ} \mathrm{C}$ for: (a) $15 \mathrm{~min}$; (b) $40 \mathrm{~min}$

40 min are shown in Fig. 10, where points A-L correspond to $\mathrm{Au}_{5} \mathrm{Sn}, \mathrm{AuSn}, \mathrm{AuSn},(\mathrm{Au}, \mathrm{Ni}) \mathrm{Sn},(\mathrm{Ni}, \mathrm{Au})_{3} \mathrm{Sn}_{2}, \mathrm{AuSn}, \mathrm{Au}_{5} \mathrm{Sn}$, $(\mathrm{Au}, \mathrm{Ni}) \mathrm{Sn}$, and $(\mathrm{Ni}, \mathrm{Au})_{3} \mathrm{Sn}_{2}$ phases, respectively. $\left.{ }^{43}\right)$ The main interfacial IMCs are $(\mathrm{Au}, \mathrm{Ni}) \mathrm{Sn}$ and $(\mathrm{Ni}, \mathrm{Au})_{3} \mathrm{Sn}_{2}$ in solder joints. When the content of $\mathrm{Ni}$ exceeds the maximum solubility in AuSn, the (Au,Ni)Sn IMC is first formed with the diffusion of $\mathrm{Ni}$ atoms during the welding, and ( $\mathrm{Au}, \mathrm{Ni}) \mathrm{Sn}$ IMC gradually transform into $(\mathrm{Ni}, \mathrm{Au})_{3} \mathrm{Sn}_{2}$ IMC. Two types of intermetallic compounds $(\mathrm{Au}, \mathrm{Ni})_{3} \mathrm{Sn}_{2}$ and $\left.(\mathrm{Au}, \mathrm{Ni})_{3} \mathrm{Sn}\right)$ can be observed in $\mathrm{Au}-20 \mathrm{Sn} / \mathrm{Ni}$ joints at a reflow temperature of $300^{\circ} \mathrm{C}$. As the temperature increases, the $(\mathrm{Au}, \mathrm{Ni})_{3} \mathrm{Sn}_{2} \mathrm{IMC}$ generally changes from elongated rods to short and thick. ${ }^{44)}$ The average diameter of $\mathrm{Au}-20 \mathrm{Sn}$ solder joints prepared by the sequential electroplating method was $80 \mu \mathrm{m}$, and the solder matrix consisted mainly of $\beta$-Sn phase and $\mathrm{AuSn}_{4}$ IMC. $\left.{ }^{45}\right)$ The $(\mathrm{Ni}, \mathrm{Au})_{3} \mathrm{Sn}_{4}$ IMC was formed at $\mathrm{Au}-20 \mathrm{Sn} / \mathrm{Ni}$ solder joint. The microstructure of the solder matrix was significantly coarsened after aging treatment at $150^{\circ} \mathrm{C}$ for $48 \mathrm{~h}$, but the solder matrix was completely transformed into $\mathrm{AuSn}_{4}$ phase after $250 \mathrm{~h}$. The matrix of the solder consisted of two relatively large $\mathrm{AuSn}_{2}$ and $\mathrm{AuSn}_{4}$ phases after $1000 \mathrm{~h}$, as shown in Fig. 11. Microstructural changes are generated by the depletion of $\mathrm{Sn}$ atoms in the solder matrix. The matrix of the solder consisted of $\mathrm{AuSn}$ IMC and $\mathrm{Au}_{5} \mathrm{Sn}$ IMC when $\mathrm{Au}-30 \mathrm{Sn}$ bumps were prepared on flip-chip using alloy coelectroplating process. $\left.{ }^{46}\right) \mathrm{Au}-30 \mathrm{Sn} / \mathrm{Ni}$ UBM solder joints first formed (Au,Ni) ${ }_{3} \mathrm{Sn}_{2}$ IMC at a reflow temperature of $400^{\circ} \mathrm{C}$. The $(\mathrm{Au}, \mathrm{Ni})_{3} \mathrm{Sn}_{2}$ began to react with the $\mathrm{Ni}$ substrate to form $(\mathrm{Au}, \mathrm{Ni})_{3} \mathrm{Sn} \mathrm{IMC}$ as the solder matrix was consumed. Lee et al $^{47)}$ explored the interfacial reaction of $\mathrm{Au}-20 \mathrm{Sn}$ with a direct-bond-copper (DBC) ceramic substrate, and found that $(\mathrm{Au}, \mathrm{Ni}) \mathrm{Sn}$ and $(\mathrm{Ni}, \mathrm{Au})_{3} \mathrm{Sn}_{2}$ IMC were formed in $\mathrm{Au}-20 \mathrm{Sn} / \mathrm{DBC}$ solder joints, and no significant growth existed in the IMC layer of the solder joints after heat treatment of $2000 \mathrm{~h}$ at $200^{\circ} \mathrm{C}$.

The addition of $\mathrm{Ni}$ to $\mathrm{Cu}$ substrates can enhance the reliability of $\mathrm{Au}-20 \mathrm{Sn}$ solder joints, so some researchers have studied the interfacial reaction about $\mathrm{Au}-20 \mathrm{Sn} / \mathrm{Ni}-\mathrm{Cu}$ solder joints. $\mathrm{Au}-20 \mathrm{Sn} / \mathrm{Ni}-20 \mathrm{Cu}$ and $\mathrm{Au}-20 \mathrm{Sn} / \mathrm{Ni}-40 \mathrm{Cu}$ solder joints form $\mathrm{Au}-\mathrm{Cu}$ phase and $\mathrm{Ni}_{3} \mathrm{Sn}_{2}$ phase, but discontinuous layered structures of $\mathrm{Ni}_{3} \mathrm{Sn}_{2}$ IMC appear in the solder joints when the content of $\mathrm{Cu}$ elements reaches 60 at $\%$ and 80 at $\%$, as shown in Fig. $12 .^{48)}$ At $350^{\circ} \mathrm{C}, \mathrm{Au}-20 \mathrm{Sn} / \mathrm{Ni}-\mathrm{Cu}$ solder joints by transient TLP consisted of $\mathrm{AuCu}, \mathrm{Ni}_{3} \mathrm{Sn}_{2}$, and $\alpha(\mathrm{An})$ phases, and the $\mathrm{AuCu}$ phase was gradually transformed into $(\mathrm{Au}, \mathrm{Cu})$ phase after 400 or $450^{\circ} \mathrm{C}$. A new 


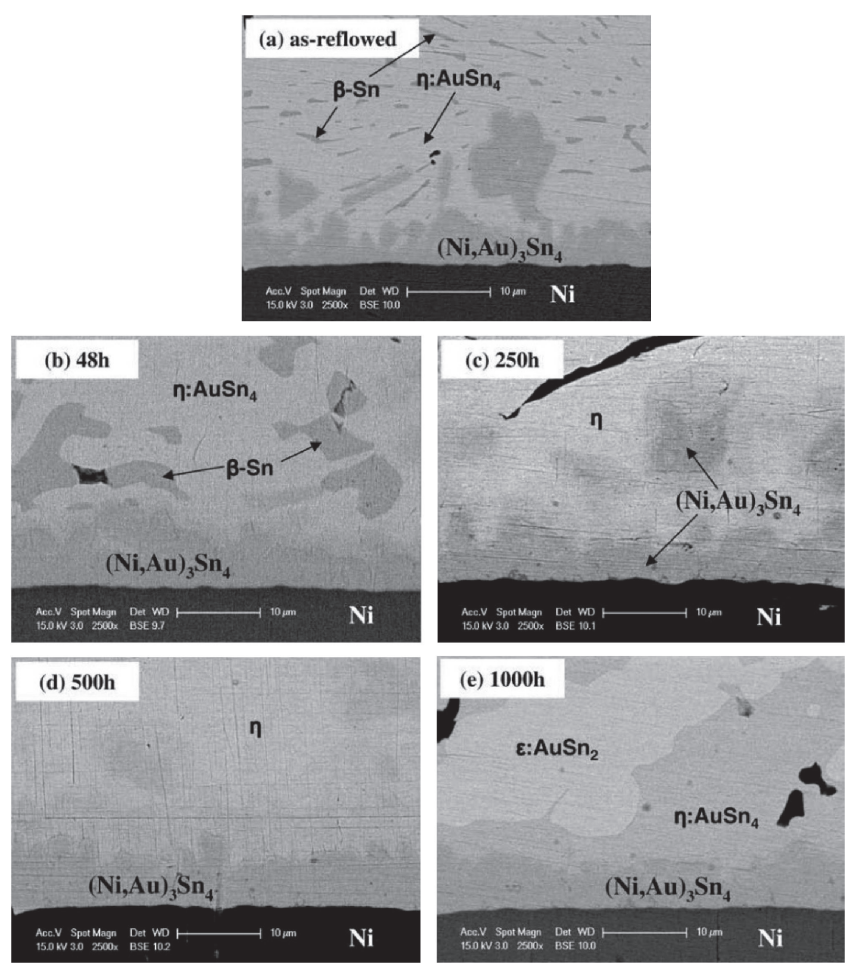

Fig. 11 The cross-sectional SEM images of the Sn-rich $\mathrm{Au}-\mathrm{Sn} / \mathrm{Ni}$ solder joint aged at $150^{\circ} \mathrm{C}$ for (a) as-reflowed, (b) $48 \mathrm{~h}$, (c) $250 \mathrm{~h}$, (d) $500 \mathrm{~h}$, and (e) $1000 \mathrm{~h}$.

$\mathrm{Ni}_{3} \mathrm{Sn}$ phase was generated between $\mathrm{Ni}_{3} \mathrm{Sn}_{2}$ and $\alpha(\mathrm{An})$ phases, as shown in Fig. 13. ${ }^{49)}$ The interfacial IMC of the $\mathrm{Ni}(\mathrm{Si}$ chip)/Au-20Sn/Ni-Cu solder joint consists of $(\mathrm{Au}, \mathrm{Ni}) \mathrm{Sn}$ and $(\mathrm{Ni}, \mathrm{Au})_{3} \mathrm{Sn}_{2} \mathrm{IMC}$, as shown in Fig. $14 .^{50)}$ After aging the solder joints at $150-200^{\circ} \mathrm{C}$ for $2000 \mathrm{~h}$, only
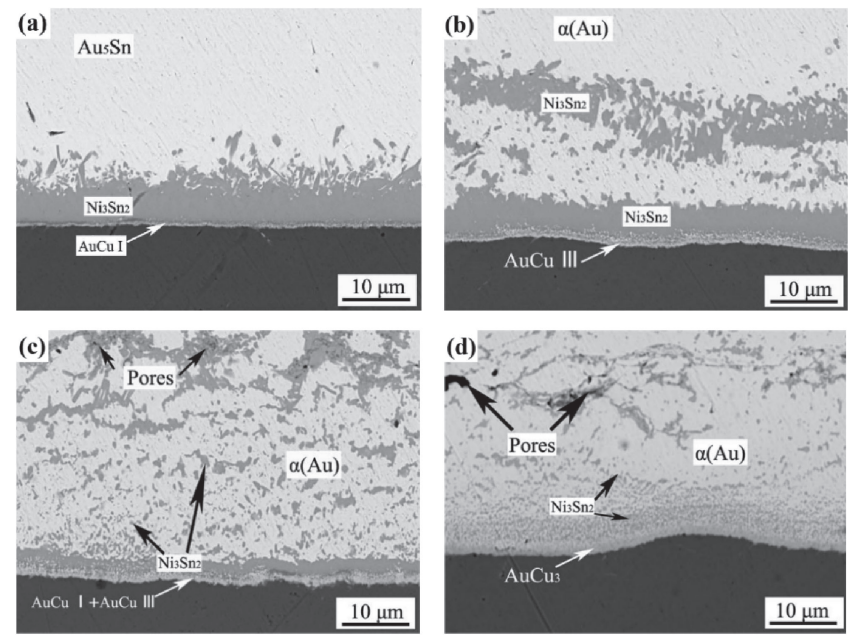

Fig. 12 The cross-section SEM images of $\mathrm{Au}-\mathrm{Sn} / \mathrm{Ni}-\mathrm{xCu}$ solder joints for 540 min soldering: (a) $\mathrm{x}=20$ at $\%$; (b) $\mathrm{x}=40$ at $\%$; (c) $\mathrm{x}=60$ at $\%$ (d) $\mathrm{x}=80$ at $\%$.

the (Au,Ni)Sn IMC remained at the interface, and no significant growth in the interfacial IMC of the solder joints was observed with increasing aging time. Therefore, the Au20Sn solder has good interfacial stability at high temperatures. The $\mathrm{Au}, \mathrm{Sn}, \mathrm{AuSn}, \mathrm{AuSn}_{2}$, and $\mathrm{AuSn}_{4} \mathrm{IMC}$ are present in the solder matrix of $\mathrm{Au} / \mathrm{Sn} / \mathrm{Au}$, and the solder reacts with Kovar alloy to form a new $(\mathrm{Ni}, \mathrm{Au})_{3} \mathrm{Sn}_{2} \mathrm{IMC}$. A thicker (Au,Ni)Sn IMC layer was formed at the interface after $24 \mathrm{~h}$ of aging treatment of the solder joint at $250^{\circ} \mathrm{C}$. As the Ni layer is consumed, the reliability is weakened, therefore, thickening the Ni layer or surface treatment of the Ni layer can better improve the reliability of the solder joint at high temperatures. ${ }^{51)}$
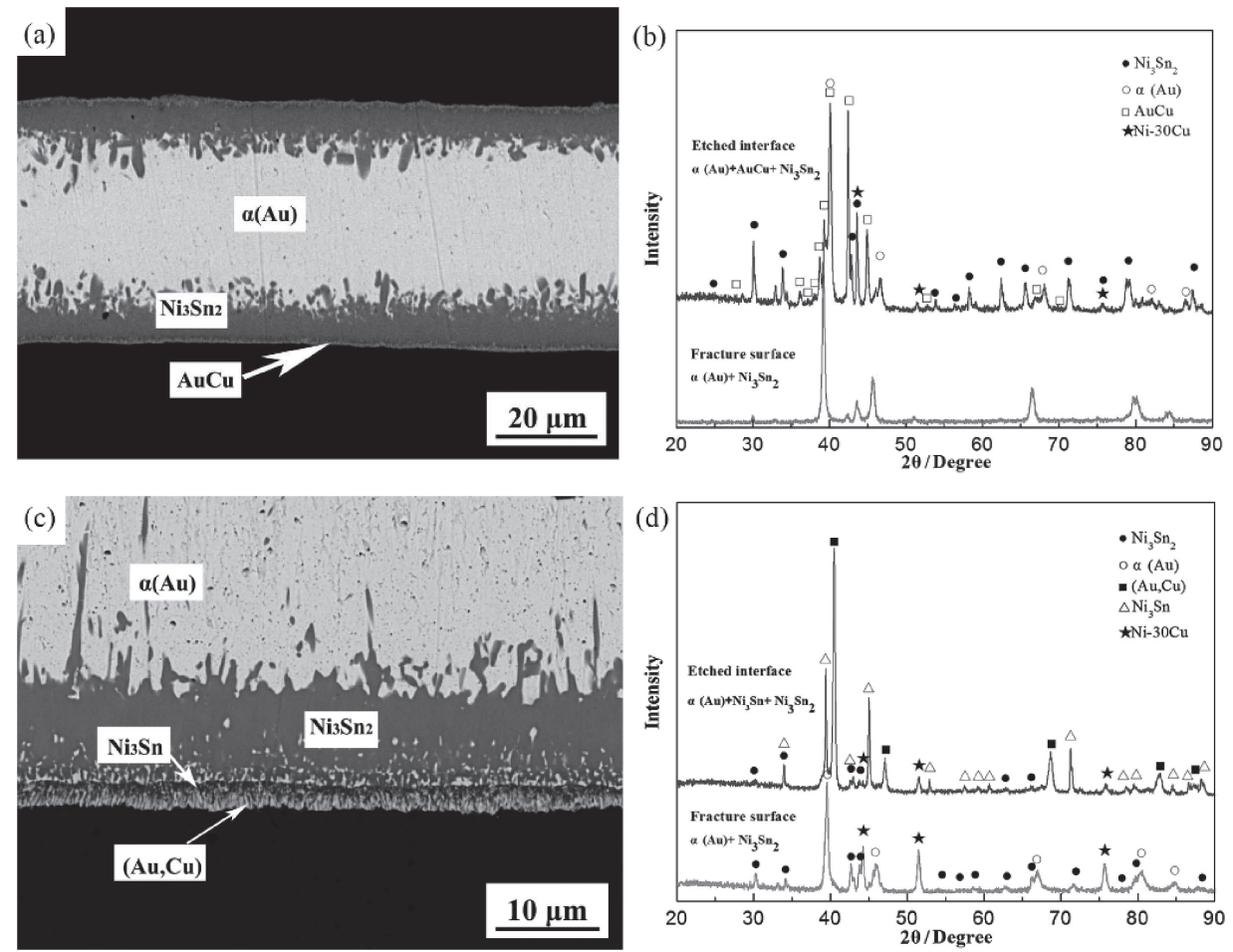

Fig. 13 TLP bonded Au-Sn/Ni-30Cu joint: (a) cross-section image; (b) XRD image of the etched interface and fracture surface; The TLP bonded $\mathrm{Au}-\mathrm{Sn} / \mathrm{Ni}-30 \mathrm{Cu}$ solder joints after exposed at $450^{\circ} \mathrm{C}$ for $24 \mathrm{~h}$ : (c) cross-section image; (d) XRD image. 


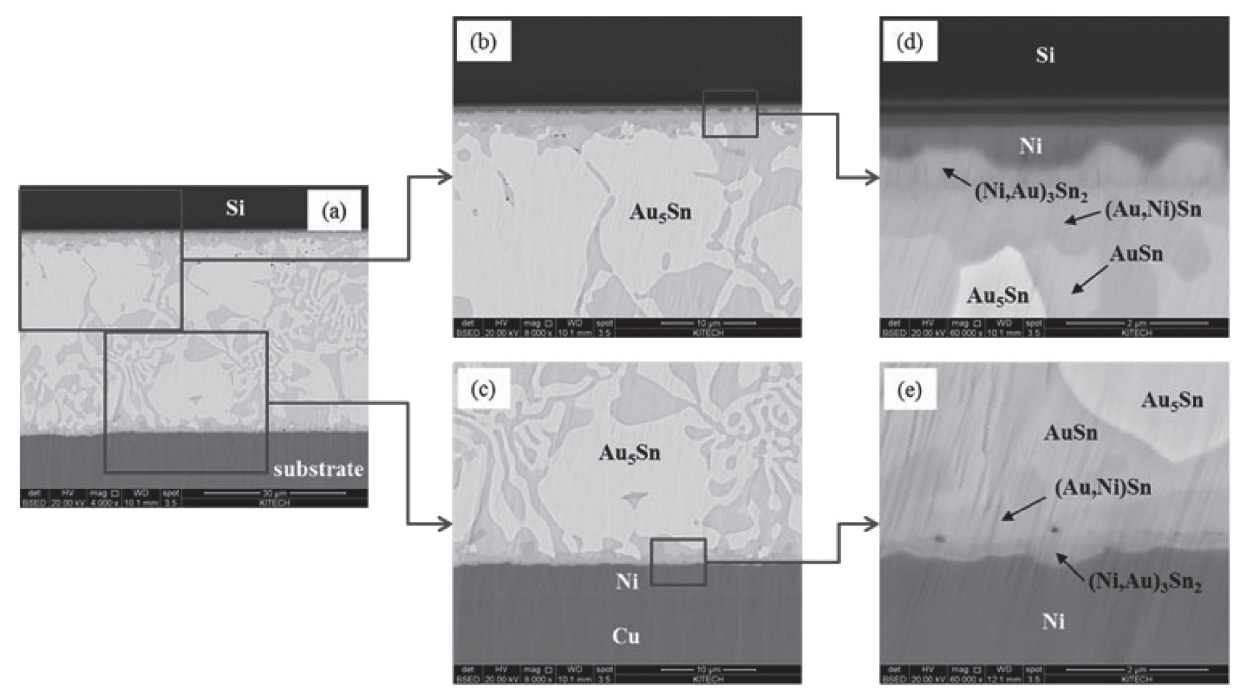

Fig. 14 (a)-(e) The cross-sectional SEM images of Ni(Si chip)/Au-20Sn/Ni(substrate) interfaces aged at $150^{\circ} \mathrm{C}$.
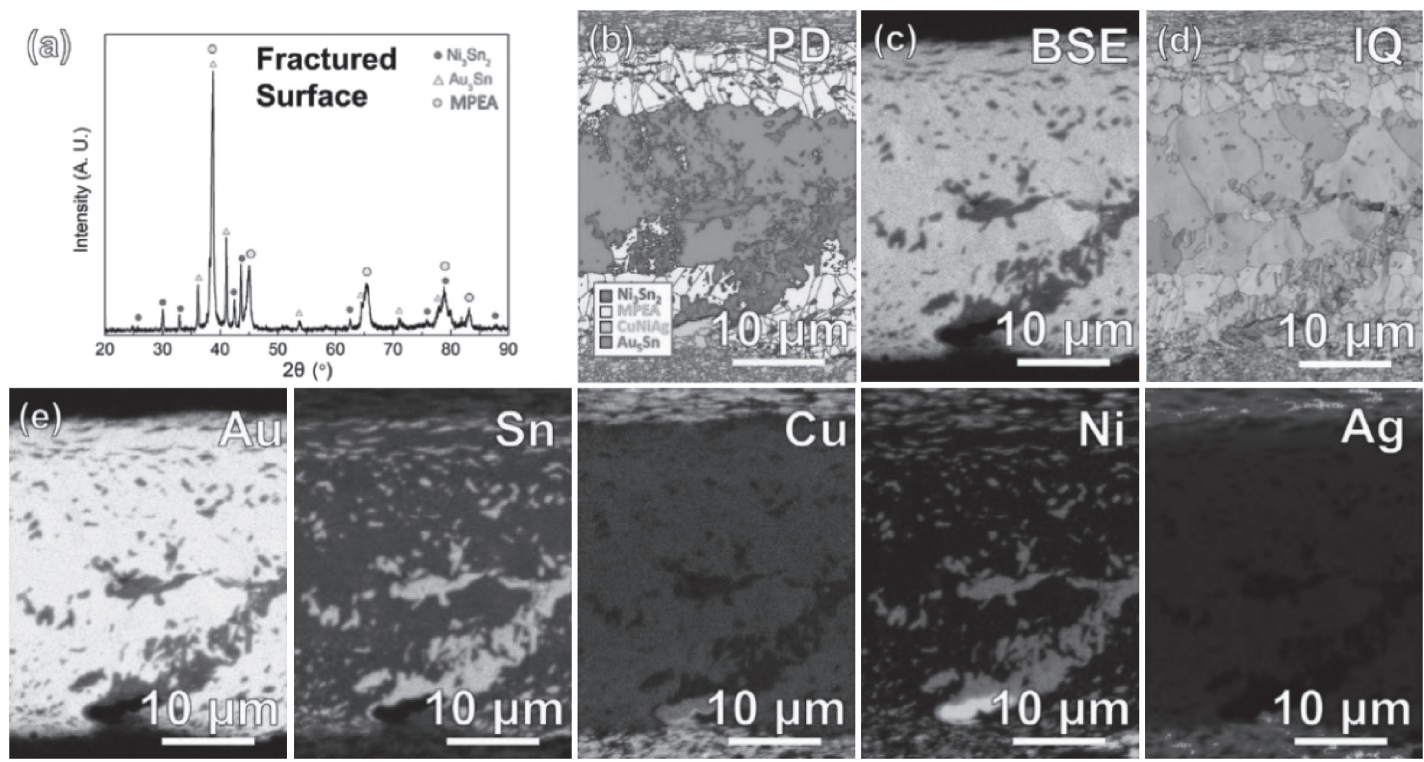

Fig. 15 The $\mathrm{CuNiAg} / \mathrm{Au}-\mathrm{Sn} / \mathrm{CuNiAg}$ solder joint after reflowing for $20 \mathrm{~min}$ at $350^{\circ} \mathrm{C}$. (a) XRD image of fractured surface. (b) EBSD phase distribution map. (c) BSE image. (d) IQ map. (e) Energy Dispersive Spectrometer (EDS) maps of Au, Sn, Ni, Cu, and Ag.

Plating the Au layer on the surface of the Ni layer can effectively inhibit the oxidation of the Ni layer and enhance the effect of solder wettability. ${ }^{52)}$ The interfacial microstructure of $\mathrm{Au}-29 \mathrm{Sn}$ bumps on $\mathrm{Cu} /$ chemically plated $\mathrm{Ni} / \mathrm{Au}$ composed of $(\mathrm{Au}, \mathrm{Ni}) \mathrm{Sn}$ and $(\mathrm{Au}, \mathrm{Ni})_{3} \mathrm{Sn}_{2} \mathrm{IMC}$ after aging at $200^{\circ} \mathrm{C}$ for 365 days. Discontinuous interfacial IMC were formed during $\mathrm{Au}-\mathrm{Sn}$ solder react with the Pt substrate, and there are localized $\mathrm{Pt}$ elements that dissolve into the molten solder during reflow. ${ }^{53)}$ The reaction behavior of $\mathrm{Ni}$ and $\mathrm{Pt}$ is similar, but the $\mathrm{Au}-\mathrm{Sn} / \mathrm{Co}$ solder joint forms continuous reaction products at a slower reaction rate, making Co more suitable than $\mathrm{Pt}$ and $\mathrm{Ni}$ as a blocking material for $\mathrm{Au}-\mathrm{Sn}$ eutectic solder in optoelectronic packages.

In addition to studying the interfacial reaction of solder on $\mathrm{Cu}, \mathrm{Ni}$, and $\mathrm{Au}$ substrates, Peng et al. ${ }^{44)}$ explored the interfacial reaction of $\mathrm{Au}-20 \mathrm{Sn} / \mathrm{UBM}(\mathrm{Al} / \mathrm{Ni}(\mathrm{V}) \mathrm{Au})$ solder joint at $300^{\circ} \mathrm{C}$ for $5 \mathrm{~min}$. The $\mathrm{Au}$ and $\mathrm{Al}$ in the UBM react to form $\mathrm{Au}_{8} \mathrm{Al}_{3}$ compounds, causing the $(\mathrm{Au}, \mathrm{Ni})_{3} \mathrm{Sn}_{2} \mathrm{IMC}$ to be too high and the solder joint to fracture at the weak point of the $(\mathrm{Au}, \mathrm{Ni})_{3} \mathrm{Sn}_{2}$ IMC. The $\mathrm{CuNiAg} / \mathrm{Au}-\mathrm{Sn} / \mathrm{CuNiAg}$ solder joint formed $\mathrm{Ni}_{3} \mathrm{Sn}_{2}$ IMC after heating at $350^{\circ} \mathrm{C}$ for 5 min, as shown in Fig. 15. ${ }^{54)}$ The AuSn matrix gradually decreased in the solder after $20 \mathrm{~min}$, while more IMC, consisting of the multi-principal-element alloys (MPEA) phase, $\mathrm{Au}_{5} \mathrm{Sn}$ and $\mathrm{Ni}_{3} \mathrm{Sn}_{2}$, was formed at the joints. The reaction process is shown in eq. (5). The components of MPEA are roughly $55 \mathrm{Au}-6 \mathrm{Sn}-23 \mathrm{Cu}-2 \mathrm{Ni}-14 \mathrm{Ag}$ (at\%). It was found that the matrix of the solder was completely transformed to the MPEA and $\mathrm{Ni}_{3} \mathrm{Sn}_{2}$ after $60 \mathrm{~min}$, as shown in eq. (6). Wen et al. ${ }^{55)}$ probed the influence of $\gamma$-ray irradiation on $\mathrm{Au}-20 \mathrm{Sn} / \mathrm{Ni}$ solder joints and found that $\gamma$-ray irradiation accelerated the reaction between $\mathrm{Ni}$ substrate and $\mathrm{Au}-\mathrm{Sn}$ solder, producing (Au,Ni)Sn IMC and $(\mathrm{Ni}, \mathrm{Au})_{3} \mathrm{Sn}_{2} \mathrm{IMC}$, as shown in Fig. 16. After $1000 \mathrm{~h}$ of irradiation, the weldability of $\mathrm{MoCu} 20 / \mathrm{Au}-20 \mathrm{Sn} / \mathrm{Cu}$ solder joints decreased from $94.7 \%$ to $88.6 \%$, and the size of the 

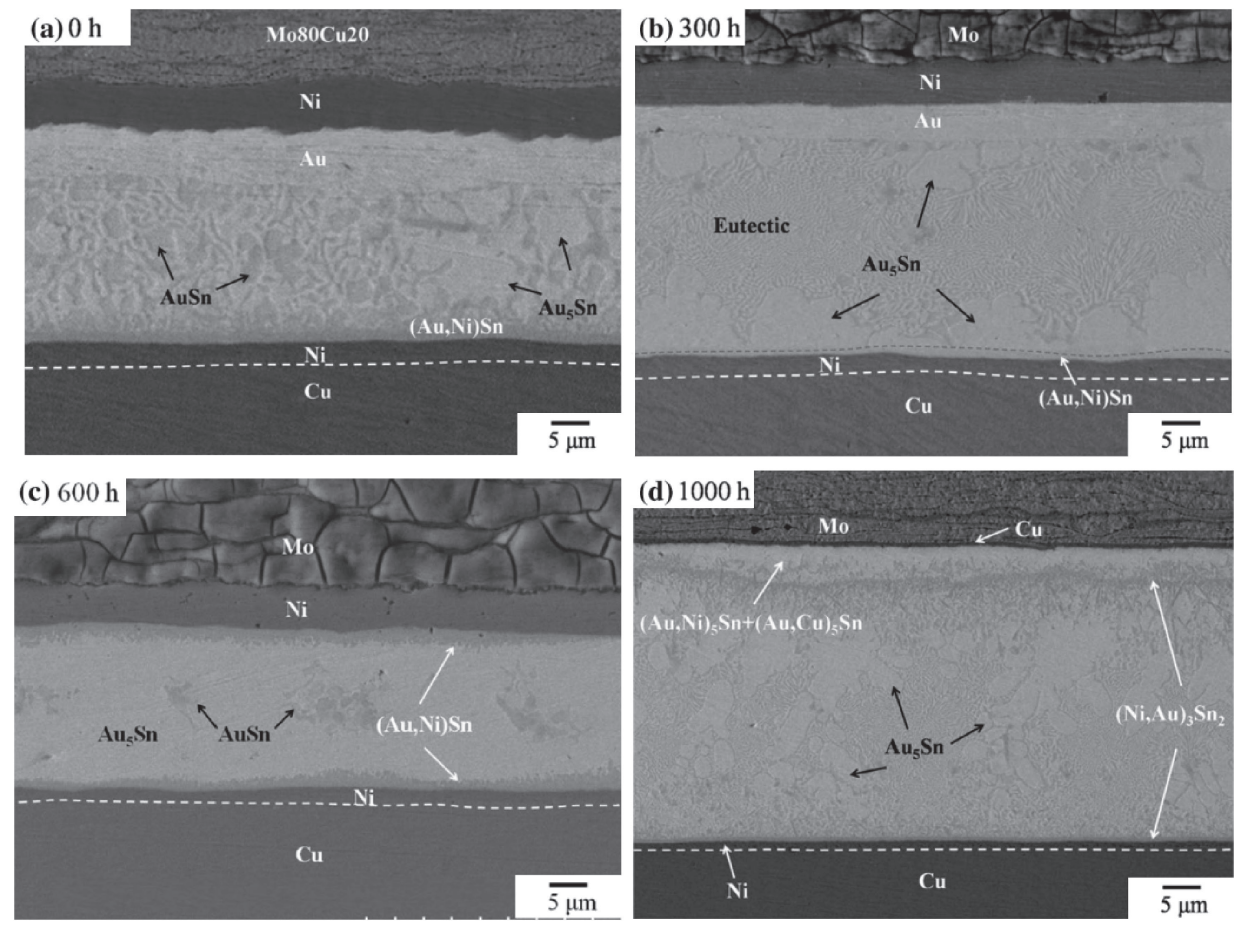

Fig. 16 SEM of MoCu20/Cu solder joints for (a) $0 \mathrm{~h}$, (b) $300 \mathrm{~h}$, (c) $600 \mathrm{~h}$, (d) $1000 \mathrm{~h}$.

holes in the solder joints increased with increasing irradiation time.

$$
\begin{gathered}
\mathrm{Au}-\mathrm{Sn}+\mathrm{CuNiAg} \rightarrow \mathrm{MPEA}+\mathrm{Ni}_{3} \mathrm{Sn}_{2}+\mathrm{Au}_{5} \mathrm{Sn} \\
\mathrm{Au}_{5} \mathrm{Sn}+\mathrm{CuNiAg} \rightarrow \mathrm{MPEA}+\mathrm{Ni}_{3} \mathrm{Sn}_{2}
\end{gathered}
$$

\section{Mechanical Properties}

$\mathrm{Au}-\mathrm{Sn}$ solders have the advantages of good creep and mechanical properties, flux-free soldering, and excellent wettability. ${ }^{16)}$ The hardness of $\mathrm{Au}-20 \mathrm{Sn}$ solder decreases with the increase of temperature in the temperature range of $25-200^{\circ} \mathrm{C}$. The rate of creep reaction increases and the stress index decreases with the increase of temperature. The main reason for the reduction of solder hardness is the hightemperature creep behavior during the heating process. ${ }^{56}$ ) Chu et al. ${ }^{13)}$ explored the mechanical properties of $\mathrm{Au}-\mathrm{Sn}$ IMC using the nanoindentation method and found that the hardness of $\mathrm{Au}_{5} \mathrm{Sn}$ and $\mathrm{AuSn}$ IMC was greater than ordinary soft solders, thus Au-Sn solders consisting of these two IMCs had higher creep resistance than ordinary solders. The good mechanical strength of $\mathrm{Au}-20 \mathrm{Sn}$ solder provides higher stability of solder joints in laser diode packages. ${ }^{57)}$ However, the cost of the solder is high because of the $80 \%$ $\mathrm{Au}$ content of $\mathrm{Au}-20 \mathrm{Sn}$ solder. In addition, its relatively high microhardness leads to poor machinability, mismatch of thermal expansion coefficient, and a tendency for solder joints to break. ${ }^{58)}$ Namazu et al. ${ }^{59)}$ used microelectromechanical system method (MEMS) to assess the mechanical properties of $\mathrm{Au}-\mathrm{Sn}$ solders. The Young's modulus and Poisson's ratio of $\mathrm{Au}-20 \mathrm{Sn}$ solders were $51.3 \mathrm{GPa}$ and 0.288 at room temperature. Young's modulus decreases with the increase of temperature, but Poisson's ratio is not affected by temperature.
The microstructure of the solders differed with different preparation processes, which led to variations in their mechanical properties. The shear strength of $\mathrm{Au}-20 \mathrm{Sn}$ solder prepared by the rapid solidification method reached $39.17 \pm$ $0.70 \mathrm{MPa}$, which is $19.02 \%$ higher than ordinary Au-20Sn solder because of the finer and more uniform grains of the solder. ${ }^{22)}$ The strength of the Au-20Sn solder prepared by PFC was reduced but plasticity was enhanced after heat treatment. The tensile strength decreased from $338.3 \mathrm{MPa}$ to $310 \mathrm{MPa}$ and the yield strength decreased from $338.3 \mathrm{MPa}$ to $180.5 \mathrm{MPa}$, while the plastic strain increased from 0 to $1.6 \%{ }^{24)}$ Flux-free $\mathrm{Au} / \mathrm{Sn}$ solder in laser diodes was heattreated at $150^{\circ} \mathrm{C}$ for 64 days, and the stress concentration resulted in a larger number and area of cavities voids in the solder joints as the aging time increased, reducing the strength of solder joint. ${ }^{60)}$ The shear strength of $\mathrm{Au}-20 \mathrm{Sn}$ solder joints prepared by the sequential electroplating method remained almost unchanged after $1000 \mathrm{~h}$ of aging at about $0.4-0.5 \mathrm{~N}$. The fracture surfaces of all solder joints were mainly concentrated at the interface of the solder joints, indicating that the fracture at the interface was related to the brittle $(\mathrm{Ni}, \mathrm{Au})_{3} \mathrm{Sn}_{4}$ IMC. $\left.{ }^{45}\right)$ Chu et al. ${ }^{61)}$ explored the influence of the continuous flip-chip soldering process on the reliability of $\mathrm{Au}-\mathrm{Sn}$ solder joints. It was observed that the reason for the decrease of mechanical strength in solder joints is the transformation of the eutectic phase to the $\zeta$ phase in the solder after several reflows.

The shear strength of $\mathrm{Au}-20 \mathrm{Sn} /(\mathrm{Sn}) \mathrm{Cu}$ solder joint increases and then decreases with the increase of reflux times. Their fracture surfaces shifted from the $\mathrm{Sn} /(\mathrm{Cu}, \mathrm{Au})_{6} \mathrm{Sn}_{5}$ layer to the $\mathrm{AuSn}_{4} /(\mathrm{Cu}, \mathrm{Au})_{6} \mathrm{Sn}_{5}$ layer and eventually to the $\mathrm{AuSn}_{2} /(\mathrm{Cu}, \mathrm{Au})_{6} \mathrm{Sn}_{5}$ layer. ${ }^{38)}$ The shear strength of the solder joint reduces continuously and the fracture surface shifts from the $\mathrm{AuSn}_{2} /(\mathrm{Cu}, \mathrm{Au})_{6} \mathrm{Sn}_{5}$ layer to the AuSn layer and 
eventually to the $\mathrm{Cu}_{3} \mathrm{Sn} / \mathrm{Cu}$ interface as the aging time increases. With the increase of aging time, the shear strength of solder joints reduces, and the fracture surface gradually shifts from the $(\mathrm{Au}, \mathrm{Cu})_{5} \mathrm{Sn} / \mathrm{Cu}$ layer to the $\mathrm{Au}-20 \mathrm{Sn}$ solder matrix. The $(\mathrm{Ni}, \mathrm{Au})_{3} \mathrm{Sn}_{2} \mathrm{IMC}$, which is formed in the interface of $\mathrm{Au}-\mathrm{Sn} / \mathrm{Ni}$ flip-chip solder joints, is gradually transformed into (Au,Ni)Sn IMC during aging at $150^{\circ} \mathrm{C}$ because the diffusion of $\mathrm{Ni}$ atoms is suppressed. ${ }^{21)}$ In addition, it was found that the brittle IMC layer at the interface cause the brittle failure of the solder joint by bump shear tests. The microstructure of $\mathrm{Au}-\mathrm{Sn} / \mathrm{Ni} / \mathrm{Kovar}$ solder joints was relatively reliable at $180^{\circ} \mathrm{C}$. At $250^{\circ} \mathrm{C}$, the solder joints fractured at the interface, indicating that the brittle IMC layer causes brittle fracture of the solder joints at the interface. ${ }^{62}$ In addition, the consumption of the Ni layer decreases the reliability of the solder joint during aging at $250^{\circ} \mathrm{C}$ in the solder joint. Therefore, the thickness of the $\mathrm{Ni}$ layer needs to be increased if we want the solder joint to have relatively good reliability at $250^{\circ} \mathrm{C}$. In summary, it can be seen that the reason for the decrease of the reliability of the solder joint is the presence of brittle interfacial IMC in the solder joint.

Enhancing the reliability of solder joints is the focus of current research at high-temperature. Au-Sn solder joints prepared by TLP usually have relatively high solder joint reliability. Peng et al. ${ }^{49)}$ found that the shear strength of $\mathrm{Au}-20 \mathrm{Sn} / \mathrm{Ni}-30 \mathrm{Cu}$ solder joints prepared by TLP reached $87 \mathrm{MPa}$ and $97 \mathrm{MPa}$ from $75 \mathrm{MPa}$ after exposure to $400^{\circ} \mathrm{C}$ and $450^{\circ} \mathrm{C}$ for $24 \mathrm{~h}$, respectively, indicating that higher temperature can advance the shear strength of TLP solder joints. The $\mathrm{Cu} / \mathrm{An}-29 \mathrm{Sn} / \mathrm{Cu}$ solder joints bonded by TLP also have good reliability. ${ }^{36)}$ The shear strength was able to remain stable at about $40 \mathrm{MPa}$ after 400 thermal cycles between 25 and $350^{\circ} \mathrm{C}$, as shown in Fig. 17. Morever, the fracture of the shear deformation of the solder joint occurs mainly in the Au6.6Cu9.6Sn3.8 phase. The TLP-bonded $\mathrm{Ni} / \mathrm{Au}-\mathrm{Sn} / \mathrm{Ni}$ solder joints have good thermal stability. ${ }^{39)}$ The shear strength was $32 \mathrm{MPa}$ and $48 \mathrm{MPa}$ at $450^{\circ} \mathrm{C}$ and room temperature, respectively. It still reached $45 \mathrm{MPa}$ after $400 \mathrm{~h}$ of treatment at $450^{\circ} \mathrm{C}$, and it decreased to only $42 \mathrm{MPa}$ after 300 thermal cycles. The Au-20Sn/DBC solder joints maintained stability and good mechanical strength at high temperatures. ${ }^{47)}$ Among the $\mathrm{Au}-20 \mathrm{Sn} / \mathrm{Ni}-\mathrm{xCu}(\mathrm{x}=20,40$, 60,80 at $\%$ ) solder joints, the $\mathrm{Au}-20 \mathrm{Sn} / \mathrm{Ni}-40 \mathrm{Cu}$ solder joints have a relatively high shear strength $(62 \mathrm{MPa})$ and good reliability. The $\mathrm{AuCu}$ layer in the solder joint was able to bond the solder and the substrate well, and the high Nicontaining $\alpha(\mathrm{Au})$ and uniformly continuous $\mathrm{Ni}_{3} \mathrm{Sn}_{2}$ IMC layers were able to inhibit the evolution of porosity, which increased the reliability of the solder joint. ${ }^{48)}$ The $55 \mathrm{Au}-6 \mathrm{Sn}-$ $23 \mathrm{Cu}-2 \mathrm{Ni}-14 \mathrm{Ag}$ IMC was formed in $\mathrm{CuNiAg} / \mathrm{Au}-\mathrm{Sn} /$ CuNiAg solder joints with yield strength of $190 \mathrm{MPa}$, Young's modulus of $100 \mathrm{GPa}$, and strain hardening rate of 0.4535. The shear strength of $\mathrm{CuNiAg} / \mathrm{Au}-\mathrm{Sn} / \mathrm{CuNiAg}$ solder joints reached $81 \mathrm{MPa}$ after bonding for $20 \mathrm{~min}$. It is $68 \%$ higher than $\mathrm{Ni} / \mathrm{Au}-\mathrm{Sn} / \mathrm{Ni}$ solder joints because the interfacial IMC of $\mathrm{CuNiAg} / \mathrm{Au}-\mathrm{Sn} / \mathrm{CuNiAg}$ solder joints is ductile and reduces the local stress concentration. ${ }^{54)}$ This makes it difficult to weld to $\mathrm{Al}$ electrodes due to the natural formation of alumina on the $\mathrm{Al}$ electrode. Lang et al. ${ }^{63)}$ studied an efficient way for welding the Al electrode by fabricating an Au-stud bump in the Al electrode with $\mathrm{Au}-$ 20Sn solder. The Au-20Sn solder reacted with Al electrode to form $\mathrm{AuAl}_{4} \mathrm{IMC}$. The shear strength reached $90 \mathrm{MPa}$ and the activation energy of the solder joint was $159 \mathrm{~kJ} / \mathrm{mol}$. In addition, the addition of $\mathrm{Ni}$ and $\mathrm{Pd}$ increased the shear modulus and Young's modulus of $\mathrm{AuSn}_{4} \mathrm{IMC}$, but the Poisson's ratio reduced. ${ }^{64)}$ The shear strength of $\mathrm{Au}-30 \mathrm{Sn}$,
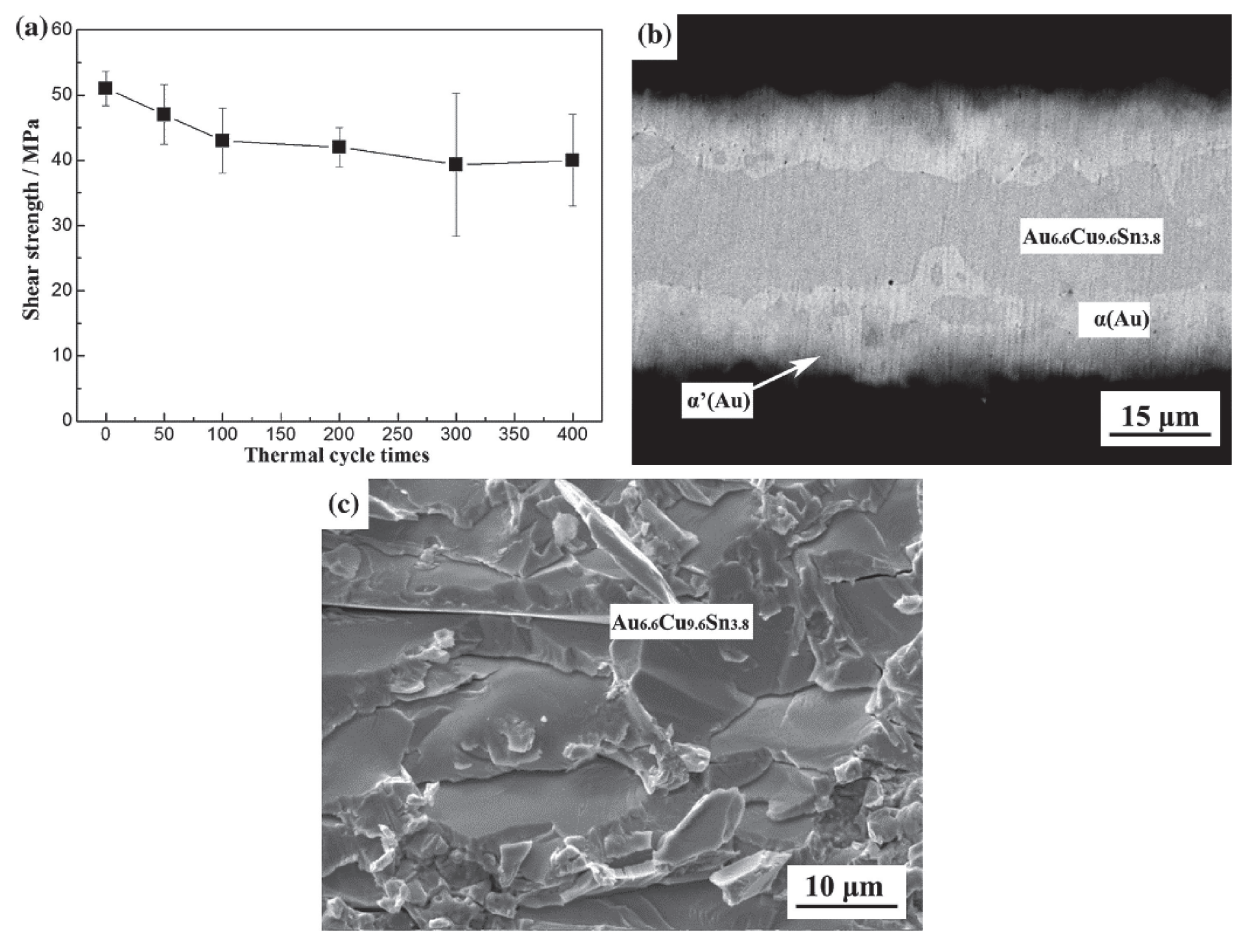

Fig. 17 (a) The relationship between shear strength of TLP-bonded joint and different thermal cycles; (b) cross-sectional image and (c) the fracture surface of TLP-bonded $\mathrm{Cu} / \mathrm{Au}-\mathrm{Sn} / \mathrm{Cu}$ solder joint after 400 cycles. 
$\mathrm{Cu} /\left(\mathrm{Sn}_{11} \mathrm{Au}_{0.5} \mathrm{Ag}_{1.5}\right) \mathrm{Sn}_{3} / \mathrm{Ni}$ and $\mathrm{Cu} /\left(\mathrm{Sn}_{11} \mathrm{Au}_{0.5} \mathrm{Ni}_{1.5}\right) \mathrm{Sn}_{3} / \mathrm{Ni}$ solder joints were $24.5 \mathrm{MPa}, 50.59 \mathrm{MPa}$ and $36.38 \mathrm{MPa}$, respectively. The shear strength of $\mathrm{Au}-30 \mathrm{Sn}$ solder joints is higher than all three of the above. ${ }^{28)}$

The microstructure of a solder joint deteriorates significantly when the oxygen content is too high in the joint. ${ }^{65)}$ The formation of oxides on the solder surface will be promoted by the high oxygen content in $\mathrm{Au}-20 \mathrm{Sn}$ solder, leading to porosity and cracks that can occur during reflow, thereby the reliability of the solder joint is decreased. ${ }^{30)}$ The $\mathrm{Au}-$ $20 \mathrm{Sn}$ solder joints had good microstructure with the oxygen content level of $16 \mathrm{ppm}$. Cracks and holes appeared in the joints with the oxygen content of $55 \mathrm{ppm}$. The shear strength of $\mathrm{Au}-20 \mathrm{Sn} / \mathrm{Cu}$ solder joints decreased by $44 \%$ from $56 \mathrm{MPa}$ to $31.7 \mathrm{MPa}$ as the oxygen content increased from $18 \mathrm{ppm}$ to $77 \mathrm{ppm}$. Some tiny pores were present at the fracture surface with the oxygen content of $18 \mathrm{ppm} .{ }^{31)}$ The pores gradually increase as the oxygen content increases.

The $\gamma$-irradiation also has an effect on the mechanical properties of the solder joint. The fracture mode of $\mathrm{Au}-20 \mathrm{Sn} /$ $\mathrm{Ni}$ joints that was not irradiated with $\gamma$-rays was ductile fracture. ${ }^{55)}$ After $300 \mathrm{~h}$ of irradiation, the fracture pattern includes ductile fracture of the Au-Sn IMC and granular fracture of the Ni layer. The fracture mode of the solder joints was completely changed from ductile fracture to brittle fracture after $600 \mathrm{~h}$ of irradiation. After $1000 \mathrm{~h}$ of irradiation, the shear strength of $\mathrm{MoCu} 20 / \mathrm{Au}-20 \mathrm{Sn} / \mathrm{Cu}$ welded joints reduced from $51.87 \mathrm{MPa}$ to $32.56 \mathrm{MPa}$, and the fracture images under different aging are shown in Fig. 18. The main reason for the reduction of shear strength was the brittle IMC in the solder joints and the defects generated by irradiation.

\section{Conclusions}

Overall, $\mathrm{Au}-20 \mathrm{Sn}$ solder is the most suitable of several eutectic solders in the Au-Sn system to use in hightemperature environments, because it has good creep resistance, corrosion resistance, fatigue resistance, and the advantages of high strength, high electrical conductivity, high thermal conductivity and flux-free soldering. However, the

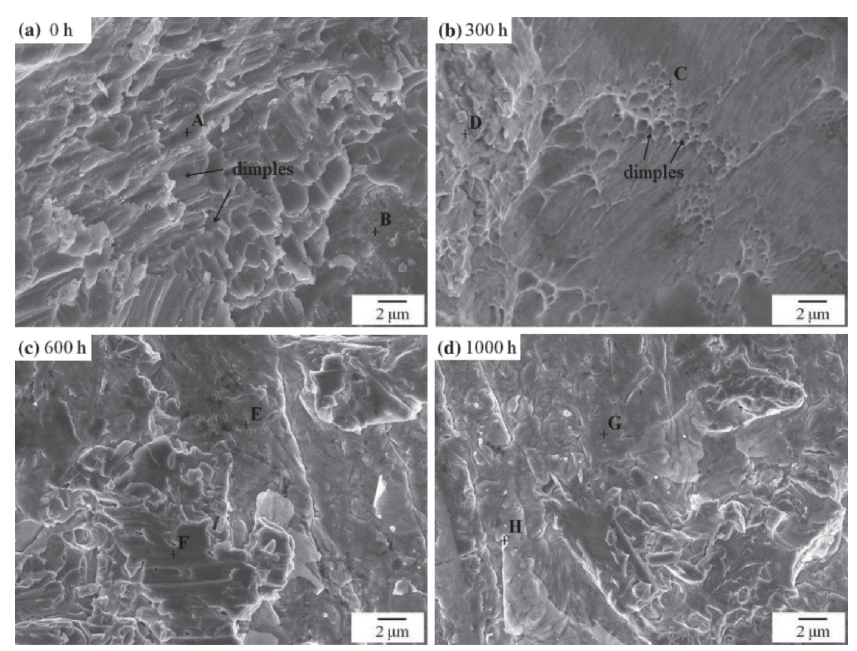

Fig. 18 The SEM images of fracture at $\mathrm{Cu}$ side of joint samples (a) $0 \mathrm{~h}$, (b) $300 \mathrm{~h}$, (c) $600 \mathrm{~h}$, (d) $1000 \mathrm{~h}$. development of $\mathrm{Au}-20 \mathrm{Sn}$ solder is constrained by several issues:

(1) Au-20Sn solder contains high content of Au elements, resulting in expensive costs.

(2) It impossible to prepare $\mathrm{Au}-20 \mathrm{Sn}$ using the conventional casting and rolling process, because the $\mathrm{Au}-20 \mathrm{Sn}$ matrix contains the brittle $\zeta-\mathrm{Au}_{5} \mathrm{Sn}$ phase.

(3) Most of the current research focuses on the interfacial IMC growth of Au-20Sn solder joints and the effect of aging treatment on solder joints, lacking a systematic research of the reliability of solder joints.

(4) Most of the research on Au-20Sn solder is conducted at the experimental stage and cannot be fully applied to the electronics industry.

The research direction of Au-20Sn solder can be started from the following points:

(1) The effects of different preparation processes on the microstructure and material properties of $\mathrm{Au}-20 \mathrm{Sn}$ solders are the focus of the study. Au-20Sn solder with more excellent properties can be produced by optimizing the process parameters, refining the grain size, and finding new processing processes.

(2) It can better reflect the failure behavior of solder joints in service and provide better theoretical support for the study of reliability by establishing the constitutive model and fatigue life prediction model of solder joints.

(3) Research on $\mathrm{Au}-20 \mathrm{Sn}$ solder should be combined with practical devices, which will have a higher application value in the future.

\section{Acknowledgments}

The present work was under support of the Key project of State Key Laboratory of Advanced Welding and Joining (AWJ-19Z04), Natural Science Foundation of Jiangsu Province of China (BK20211351), Postgraduate Research \& Practice Innovation Program of Jiangsu Normal University (2021XKT0365).

\section{REFERENCES}

1) H. Wang, X. Hu, X. Jiang and Y. Li: J. Manuf. Process. 62 (2021) 291301.

2) X. Hu, H. Xu, W. Chen and X. Jiang: J. Manuf. Process. 64 (2021) 648-654.

3) L. Zhang, W.M. Long and F.J. Wang: J. Mater. Sci. Mater. Electron. 31 (2020) 6645-6653.

4) M.L. Li, L. Zhang, N. Jiang, L. Zhang and S.J. Zhong: Mater. Des. 197 (2021) 1099224.

5) N. Jiang, L. Zhang, K.K. Xu, M.L. Li and F.J. Wang: Int. J. Mod. Phys. B 35 (2021) 2466-2480.

6) S. Tian, Y.S. Liu, Q. Ma, P.G. Zhang, J. Zhou, F. Xue and Z.M. Sun: Appl. Surf. Sci. 539 (2021) 148135.

7) L. Zhang, Z.Q. Liu, F. Yang and S.J. Zhong: Materials 10 (2017) 327.

8) M.Y. Xiong and L. Zhang: J. Mater. Sci. 54 (2019) 1741-1768.

9) S.Y. Chang, J.Y. Lee, Y.H. Huang and A.B. Wu: Appl. Sci.-Basel 9 (2019) 19.

10) M. Lederer, A.B. Kotas and G. Khatibi: Microelectron. Reliab. 114 (2020) 113888.

11) C.J. Müller, V. Bushlya, M. Ghasemi, S. Lidin, M. Valldor and F. Wang: J. Mater. Sci. 50 (2015) 7808-7820.

12) G. Zeng, S. McDonald and K. Nogita: Microelectron. Reliab. 52 (2012) 1306-1322.

13) R.R. Chromik, D.N. Wang, A. Shugar, L. Limata, M.R. Notis and R.P. 
Vinci: J. Mater. Res. 20 (2005) 2161-2172.

14) J. Ciulik and M.R. Notis: J. Alloy. Compd. 191 (1993) 71-78.

15) X.F. Wei, Y.K. Zhang, R.C. Wang and Y. Feng: Microelectron. Reliab. 53 (2013) 748-754.

16) J. Xie, S. Lu, Y. Du, W. Hu and Y. Mao: J. Alloy. Compd. 806 (2019) 1285-1291.

17) Y. Huang, W. Liu, Y. Ma, Y. Wang and S. Tang: J. Mater. Sci. Mater Electron. 29 (2018) 436-445.

18) T. Yamada, K. Miura, M. Kajihara, N. Kurokawa and K. Sakamoto: J. Mater. Sci. 39 (2004) 2327-2334.

19) X. Wei, R. Wang, Y. Feng, X. Zhu and C. Peng: Rare Met. 30 (2011) $627-632$.

20) H. Xu, V. Vuorinen, H. Dong and M. Paulasto-Kröckel: J. Alloy. Compd. 619 (2015) 325-331.

21) J.W. Yoon, H.S. Chun and S.B. Jung: J. Mater. Res. 22 (2007) 12191229.

22) S. Liu, D. Zhang, J. Xiong, C. Chen, T. Song, L. Liu and S. Huang J. Alloy. Compd. 781 (2019) 873-882.

23) S. Tabatabaei, A. Kumar, H. Ardebili, P.J. Loos and P.M. Ajayan Microelectron. Reliab. 52 (2012) 2685-2689.

24) K.A. Lee, Y.M. Jin, Y.H. Sohn, J. Namkung and M.C. Kim: Met Mater. Int. 17 (2011) 7-14.

25) J. He, D. Zhu, C. Deng, K. Xiong, J. Xie, Y. Mao and J. Li: J. Alloy Compd. 831 (2020) 154824.

26) J. He, Y. Sun, D. Zhu, K. Xiong, S. Zhang, J. Li and Y. Mao: Mater Charact. 166 (2020) 110459.

27) M. Zhao, L. Zhang, Z.Q. Liu, M. Xiong, L. Sun, N. Jiang and K.K. Xu: J. Mater. Sci. Mater. Electron. 30 (2019) 15054-15063.

28) M.L. Huang, Y.C. Yang, Y. Chen and C. Dong: Mater. Sci. Eng. A 664 (2016) 221-226

29) P.T. Vianco, A.C. Kilgo and B.M. McKenzie: J. Electron. Packag. 140 (2018) 021003

30) L. Wang, S. Xue and H. Liu: J. Mater. Sci. Mater. Electron. 29 (2018) 21130-21137.

31) Y. Li, D. Wu, Y. Zhang, L. Wang and S. Xue: Crystals 11 (2021) 601.

32) C.Y. Ho, C.W. Lin, Y.Y. Lee and S.C. Cheng: Mater. Lett. 275 (2020) 128103.

33) H.M. Chung, C.M. Chen, C.P. Lin and C.J. Chen: J. Alloy. Compd. 485 (2009) 219-224

34) H. Etschmaier, J. Novák, H. Eder and P. Hadley: Intermetallics 20 (2012) 87-92.

35) J.W. Yoon, H.S. Chun, H.J. Lee and S.B. Jung: J. Mater. Res. 22 (2007) 2817-2824.

36) J. Peng, H.S. Liu, H.B. Ma, X.M. Shi and R.C. Wang: J. Mater. Sci. 53 (2018) 9287-9296.

37) C. Du, R. Soler, B. Völker, K. Matoy, J. Zechner, G. Langer, M. Reisinger, J. Todt, C. Kirchlechner and G. Dehm: Materialia 8 (2019) 100503.

38) W. Liu, Y. Wang, Y. Ma, Q. Yu and Y. Huang: Mater. Sci. Eng. A 651 (2016) 626-635
39) M. Wang, H. Liu, R. Wang and J. Peng: Mater. Sci. Eng. A 773 (2020) 138738

40) J.Y. Tsai, C.W. Chang, C.E. Ho, Y.L. Lin and C.R. Kao: J. Electron Mater. 35 (2006) 65-71.

41) H.Q. Dong, V. Vuorinen, X.W. Liu, T. Laurila, J. Li and M. PaulastoKröckel: J. Electron. Mater. 45 (2016) 566-575.

42) J.Y. Tsai, C.W. Chang, Y.C. Shieh, Y.C. Hu and C.R. Kao: J. Electron. Mater. 34 (2005) 182-187.

43) W. Liu, Y. Wang, Y. Ma, Q. Yu and Y. Huang: Mater. Sci. Eng. A 653 (2016) 13-22.

44) S.S. Kim, J.H. Kim, S.W. Booh and T.G. Kim: Mater. Trans. 46 (2005) 2400-2405.

45) J.W. Yoon, H.S. Chun, B.I. Noh, J.M. Koo, J.W. Kim, H.J. Lee and S.B. Jung: Microelectron. Reliab. 48 (2008) 1857-1863.

46) J.W. Yoon, H.S. Chun, J.M. Koo and S.B. Jung: Microsyst. Technol. 13 (2007) 1463-1469.

47 B.S. Lee, Y.H. Ko, J.H. Bang, C.W. Lee, S. Yoo, J.K. Kim and J.W. Yoon: Microelectron. Reliab. 71 (2017) 119-125.

48) J. Peng, R.C. Wang, M. Wang and H.S. Liu: J. Electron. Mater. 46 (2017) 2021-2029.

49) J. Peng, R.C. Wang, H.S. Liu and J.Y. Li: J. Mater. Sci. Mater. Electron. 29 (2018) 313-322.

50) B.S. Lee, C.W. Lee and J.W. Yoon: Surf. Interface Anal. 48 (2016) $493-497$.

51) J.W. Yoon and S.B. Jung: Microelectron. Eng. 84 (2007) 2634-2639.

52) H.G. Song, J.P. Ahn and J.W. Morris: J. Electron. Mater. 30 (2001) 1083-1087.

53) J.H. Park, J.H. Lee, Y.H. Lee and Y.S. Kim: J. Electron. Mater. 31 (2002) 1175-1180

54) J. Peng, H. Liu, L. Fu and A. Shan: J. Alloy. Compd. 852 (2021) 157015

55) L. Wen, S. Xue, J. Wang, W. Long and S. Zhong: J. Mater. Sci. Mater. Electron. 30 (2019) 9489-9497.

56) Y.C. Liu, J.W.R. Teo, S.K. Tung and K.H. Lam: J. Alloy. Compd. 448 (2008) 340-343.

57) J.W. Ronnie Teo, F.L. Ng, L.S. Kip Goi, Y.F. Sun, Z.F. Wang, X.Q. Shi, J. Wei and G.Y. Li: Microelectron. Eng. 85 (2008) 512-517.

58) Y. Du, C. Li, B. Huang, M. Tang and C. Du: Solder. Surf. Mt. Technol. 27 (2015) 7-12.

59) T. Namazu, H. Takemoto, H. Fujita and S. Inoue: Sci. Technol. Adv. Mater. 8 (2007) 146-152.

60) M.T. Sheen, Y.H. Ho, C.L. Wang, K.C. Hsieh and W.H. Cheng: J. Electron. Mater. 34 (2005) 1318-1323.

61) K. Chu, S. Park, C. Lee and Y. Sohn: J. Mater. Sci. Mater. Electron. 27 (2016) 9941-9946

62) J.W. Yoon, B.I. Noh and S.B. Jung: J. Mater. Sci. Mater. Electron. 22 (2011) 84-90.

63) F. Lang, H. Nakagawa and H. Yamaguchi: Gold Bull. 47 (2014) 109_ 118.

64) Y. Tian, W. Zhou and P. Wu: J. Electron. Mater. 45 (2016) 4138-4147.

65) L. Wang, S. Xue, Y. Lin and H. Chen: Vacuum 181 (2020) 109754. 